\title{
Thermal energy storage using chloride salts and their eutectics
}

\author{
Philip D. Myers, Jr., first author \\ Clean Energy Research Center \\ Department of Chemical and Biomedical Engineering \\ University of South Florida \\ 4202 E. Fowler Ave., ENB118 \\ Tampa FL 33620 \\ philipmyers@mail.usf.edu \\ D. Yogi Goswami, second author ${ }^{1}$ \\ Clean Energy Research Center \\ Department of Chemical and Biomedical Engineering \\ University of South Florida \\ 4202 E. Fowler Ave., ENB118 \\ Tampa FL 33620 \\ goswami@usf.edu
}

\section{ABSTRACT}

Achieving the goals of the U.S. Department of Energy (DOE) Sunshot initiative requires 1) higher operating temperatures for concentrating solar power (CSP) plants to increase theoretical efficiency, and 2) effective thermal energy storage (TES) strategies to ensure dispatchability. Current inorganic salt-based TES systems in large-scale CSP plants generally employ molten nitrate salts for energy storage, but nitrate salts are limited in application to lower temperatures-generally, below $600^{\circ} \mathrm{C}$. These materials are sufficient for parabolic trough power plants, but they are inadequate for use at higher temperatures. At the higher operating temperatures achievable in solar power tower-type CSP plants, chloride salts are promising candidates for application as TES materials, owing to their thermal stability and generally lower cost compared to nitrate salts.

In light of this, a recent study was conducted, which included a preliminary survey of chloride salts and binary eutectic systems that show promise as high temperature TES media. This study provided some basic information about the salts, including phase equilibria data and estimates of latent heat of fusion for

\footnotetext{
${ }^{1}$ Corresponding author
}

Goswami 
Applied Thermal Engineering

some of the eutectics. Cost estimates were obtained through a review of bulk pricing for the pure salts among various vendors.

This review paper updates that prior study, adding data for additional salt eutectic systems obtained from the literature. Where possible, data are obtained from the thermodynamic database software, FactSage. Radiative properties are presented, as well, since at higher temperatures, thermal radiation becomes a significant mode of heat transfer. Material compatibility for inorganic salts is another important consideration (e.g., with regard to piping and/or containment), so a summary of corrosion studies with various materials is also presented. Lastly, cost data for these systems are presented, allowing for meaningful comparison among these systems and other materials for TES applications. Because chloride salts may be employed as either sensible heat storage in the molten phase or as sensible and latent heat thermal energy storage (LHTES) as phase change materials (PCMs), cost of the candidate salt systems are presented on a cost per unit mass basis (sensible heat storage application) and a cost per unit latent heat of fusion basis (latent heat storage application). A total of 133 chloride salt systems were investigated.

Keywords: molten salt, thermal energy storage, PCM, FactSage 


\section{INTRODUCTION}

The next generation of concentrating solar power (CSP) will likely require new technologies to ensure consistent and reliable power generation that would allow it to better compete with conventional fossil fuelbased power. A good benchmark for assessing the success of solar power in this regard is that put forward by the U.S. Department of Energy (DOE) Sunshot Initiative: levelized cost of electricity (LCOE) of $\$ 0.06 / \mathrm{kWh}$ or less [1]. Achieving the goals of the U.S. DOE Sunshot initiative will require technical developments in two areas in particular. Firstly, CSP plants will need to operate at higher temperatures, which allow for increased Carnot efficiency. Secondly, viable thermal energy storage (TES) strategies are needed to ensure dispatchability. Inorganic salts are in general well-suited to address both the higher operating temperature needs of solar power towers and the attendant need for TES, as they can be used as heat transfer fluids (HTFs) and/or thermal storage media in advanced high-temperature CSP plants [2,3]. Current inorganic salt-based TES systems in large-scale CSP plants generally employ molten nitrate salts for energy storage-typically, in dualtank storage arrangements $[4,5]$-but nitrate salts are limited in application to lower temperaturesgenerally, below $600^{\circ} \mathrm{C}[6,7]$. These materials are sufficient for parabolic trough power plants, but they are inadequate for use at higher temperatures. In recent years central receivers for the solar power tower configuration produced fluid temperatures in excess of $950^{\circ} \mathrm{C}[8]$. The central receiver design is limited in operating temperature by material constraints, but it is generally regarded that gaseous fluids (e.g., air) can be reliably heated to $800-1100^{\circ} \mathrm{C}$ [9]. At the higher operating temperatures achievable in solar power towertype CSP plants, chloride salts are promising candidates for application as TES materials, owing to their thermal stability and generally lower cost compared to nitrate salts [10]. Many chloride salts are stable at these higher temperatures and tend to have low vapor pressure up to $801^{\circ} \mathrm{C}$ [11]. (An exception is $\mathrm{NiCl}_{2}$, which has a relatively high vapor pressure, as will be discussed later in this paper $[12,13]$. 
In light of this, a recent study was conducted, which included a preliminary survey of chloride salts and binary eutectic systems that show promise as high temperature TES media [14, 15]. This study provided some basic information about the salts, including phase equilibria data and estimates of latent heat of fusion for some of the eutectics. Eutectic compositions of the salts were estimated using the thermodynamic database software, FactSage $[16,17]$. Cost estimates were obtained through a review of bulk pricing for the pure salts among various vendors [18].

This review paper updates that prior study, adding data for a number of additional eutectic systems obtained from a review of the literature. Where possible, data are obtained from the thermodynamic database software, FactSage $[16,17]$. Radiative properties are presented, as well, since at higher temperatures, thermal radiation becomes a significant mode of heat transfer, and this topic has drawn some attention lately [19]. Material compatibility for inorganic salts is another important consideration (e.g., with regard to piping and/or containment), so a summary of corrosion studies with various materials is also presented. Lastly, cost data for these systems are presented, allowing for meaningful comparison among these systems and other materials for TES applications. Because chloride salts may be employed as either sensible heat storage in the liquid phase or as sensible and latent heat thermal energy storage (LHTES) as phase change materials (PCMs), cost of the candidate salt systems are presented on a cost per unit mass basis (sensible heat storage application) and a cost per unit latent heat of fusion basis (latent heat storage application).

\section{BACKGROUND}

TES is especially important in power generation, and has a primary advantage over technologies such as mechanical (e.g., compressed air storage) or chemical (e.g., batteries) in that it generally entails lower 
capital cost $[20,21]$. Further, for solar thermal power plants, TES is preferable over other storage technologies because it allows for a smaller turbogenerator with less part-time operation [9]. Here, we describe some of the general aspects of TES and go through some of the historical work with chloride salts in particular. More information on the technological details on solar power plants can be found in the review by Barlev et al [22]; extensive review of the importance and practical design concerns of TES in concentrating solar power plants can be found in the work by Kuravi et al [21].

TES can generally be divided into three distinct categories: sensible heat, latent heat, and thermochemical energy [23]. Sensible heat is perhaps the most familiar; it stores thermal energy by heating a mass of material of constant phase (e.g., solid, liquid, or vapor phase) from a lower temperature to a higher temperature, and its quantification requires knowledge of the material's specific heat capacity $\left(C_{p}\right)$, which itself may vary with temperature. Latent heat, on the other hand, stems from a phase change and corresponding change in the enthalpy of the storage medium. As such, latent heat storage makes use of PCMs, and it has the potential to offer great improvements over sensible heat storage alone, due to the typically large quantities of energy required for phase change and the potential to store / deliver heat at a constant temperature-that is, the phase-change temperature [24]. Additionally, PCMs are attractive options because, when combined in series so as to be stratified according to melting temperature, they form a cascade LHTES unit, which provides greater exergetic efficiency [25]. Thermochemical storage is very promising because of its potential for significant energy storage density [26]; however, it faces a number of technical challenges, and it will not be discussed in this paper.

A generalized phase-change process is illustrated in Figure 1 [14]. As shown, the phase change employed for TES may be solid-solid (i.e., $\alpha$-phase to $\beta$-phase), solid-liquid, or liquid-vapor (solid-vapor, or sublimation, is also technically possible in many materials). As a matter of practicality, solid-liquid PCM 
materials have received the most attention-evaporative processes tend to require more rigorous containment controls (either pressurized containers or substantially larger containment volumes) [27], and solid-solid phase change enthalpies tend to be significantly lower in magnitude than those of solid-liquid phase changes [28].

Molten salts in utility-scale storage systems - the two-tank storage system design-are wellestablished [29, 30]. Indeed, multiple power plants soon to come online will make use of this storage strategy, including the Crescent Dunes project in Tonopah, Nevada [26]. In this way, inorganic salts are very promising as high-temperature heat transfer fluids and sensible thermal storage media in solar thermal power production. It is also important to note that these materials are characterized by high heats of fusion, so their use as PCMs in LHTES arrangements can allow for substantially higher energy storage density than their use as sensible heat storage alone.

The operating temperature is a crucial factor in determining the potential upper-limit efficiency of a thermal power plant's power cycle, as well as the exergetic efficiency of any TES system meant to support the plant [26]. Higher operating temperatures and thermal storage strategies are therefore crucial to allowing CSP technologies to achieve the goals put forth by the U.S. Department of Energy Sunshot Initiative-namely, LCOE of $\$ 0.06 / \mathrm{kWh}$ or less [1]. Chloride salts are promising materials to meet the higher operating temperature needs of the next generation of CSP plants, mainly because they tend to have higher melting temperatures $-\mathrm{NaCl}$, for instance, melts at $800.7^{\circ} \mathrm{C}$ [31]. Moreover, many chloride salts are comparatively inexpensive. The review conducted by Hoshi et al, for instance, shows chloride salts in general to be less expensive per kWh latent heat than corresponding nitrates, fluorides, hydroxides, carbonates [10]. Chloride salts have been proposed as LHTES media for some time. Clayton's design report for a TES system to accompany a solar thermal power plant proposed two ternary chloride salt eutectics as PCMs: $\mathrm{KCl}-$ 
$\mathrm{NaCl}-\mathrm{MgCl}_{2}$ and $\mathrm{KCl}-\mathrm{NaCl}-\mathrm{CaCl}_{2}$ [32]. Kamimoto suggested two pure chloride salts, $\mathrm{FeCl}_{3}$ and the double salt, $\mathrm{KMgCl}_{3}$, as promising LHTES media [33]. Still, not much has been done to address their potential use as sensible heat storage media in the molten state, as nitrates are currently. Marcus suggested chlorides as potential LHTES and at the same time neglected their potential use as sensible storage media in the liquid state [34]. Rather, in that survey of TES media, nitrate salts were suggested for sensible heat storage uses, and a fluoride eutectic was proposed for possible future applications where higher temperatures were possible. As early as 1983, Radosevich and coworkers lamented the comparative lack of development in the realm of high temperature sensible heat storage HTFs in the context of various TES technological development; at that time they were predominantly limited to HITEC salt (a commercially available mixture of sodium nitrate, potassium nitrate, and calcium nitrate [35]) and other nitrate salts [36]. Interestingly, that review does not suggest chloride salts as an option, despite the fact that they make reference to an early Japanese project which used chloride salts in a novel storage scheme. That study, authored by Tanaka, describes the use of the $\mathrm{KCl}-\mathrm{LiCl}$ eutectic system as a PCM for superheating steam in a dual stage TES unit in which the main stage sensible heat storage is provided by pressurized water [37]. Venkasetty and LeFrois, likewise, proposed chloride salts (e.g., $\mathrm{NaCl}, \mathrm{LiCl}$ ) for inclusion in LHTES systems, but only as part of mixtures with other types of salts - for example, a high concentration nitrate mixture of $\mathrm{NaNO}_{3}, \mathrm{NaCl}$, and $\mathrm{Na}_{2} \mathrm{SO}_{4}$ [38]. Abe and coworkers proposed several chloride salt systems for LHTES, the result of an extensive survey of potential PCMs; these included binary, ternary, and quaternary eutectics of $\mathrm{NaCl}, \mathrm{KCl}, \mathrm{CaCl}_{2}, \mathrm{MnCl}_{2}$, and $\mathrm{MgCl}_{2}$, as well as mixtures of chlorides with other types of salts [39].

\section{THERMOPHYSICAL PROPERTIES DATA}

FactSage 
In the process of screening potential salts based on estimated cost and sufficiently high melting temperature $\left(>400 C^{\circ}\right)$, it became clear that, when considering mixtures of these materials, systems of interest would include mixtures with little thermophysical properties data immediately available in the literature. As such, the thermophysical properties database software, FactSage, was used to model the eutectic salt mixtures considered here $[17,40]$. FactSage 6.4 was used with the database FTSalt to model the binary and higher order eutectic systems of the pure salts obtained from the first screening. Most of the eutectic systems considered here have been "optimized" by the software developers - that is, they have been closely correlated to experimental phase equilibria data from various literature sources.

The optimization process is described in a series of papers by Pelton, Robelin, and coworkers [41]. Initial work in the optimization of the $\mathrm{LiCl}-\mathrm{NaCl}-\mathrm{KCl}-\mathrm{RbCl}-\mathrm{CsCl}-\mathrm{MgCl}_{2}-\mathrm{CaCl}_{2}$ system is described in the work of Chartrand and Pelton [42]. A modified quasi-chemical model for short-range ordering is utilized for the liquid phase to determine the thermodynamic properties and phase equilibria of binary and ternary systems of those salts. A variety of literature sources were used to ensure agreement between the modeled system and experimental data. Later work focused on $\mathrm{MgCl}_{2}, \mathrm{CaCl}_{2}$, and a series of divalent transition metal chlorides [13]. In this case, data from the JANAF Thermochemical Tables was used for the thermodynamic properties of the pure components, with two exceptions [12]. A slightly smaller enthalpy of fusion of $\mathrm{CoCl} 2$ was chosen to ensure self-consistency of the thermodynamic functions, and the melting temperature for $\mathrm{NiCl}_{2}$ was chosen from work involving higher pressure environments, due to its relatively high vapor pressure [43]. After some work with the ternary system of $\mathrm{NaCl}-\mathrm{KCl}-\mathrm{AlCl}_{3}$ [44], the prior divalent chlorides study was expanded to include $\mathrm{NaCl}$ and $\mathrm{KCl}$ in the system [45]. The density model in FactSage applies to the $\mathrm{NaCl}, \mathrm{KCl}, \mathrm{MgCl}_{2}$, and $\mathrm{CaCl}_{2}$, salts and their interrelated systems, and its development is described in the paper by Robelin et al [46]. The system of $\mathrm{NaCl}-\mathrm{KCl}-\mathrm{MgCl} 2-\mathrm{CaCl} 2-\mathrm{ZnCl} 2$ was optimized in a later study [47]. 
For our purposes, if a binary salt system was shown to have no congruently melting eutectic composition (e.g., a monotectic system such as $\mathrm{MgCl}_{2}-\mathrm{MnCl}_{2}$ ), then that system was excluded from further consideration. Such a salt, while inappropriate for LHTES, may be used in the molten state as a working fluid or sensible heat storage medium, however. Also, peritectic compositions of the salts were neglected in our study, so as to simplify the analysis somewhat and ensure congruent phase change if the salts were to be used for LHTES. Here again, these compositions may be used as liquid-phase sensible heat storage media.

Other researchers have worked with FactSage to help elucidate the problem of TES material selection. Notably, Gomez used FactSage to conduct a survey of binary, ternary, and quaternary fluoride, chloride, and mixed salt eutectic systems [48]. However, it should be noted that some of the listed eutectics in that study are actually peritectics in pseudo binary systems involving the decomposition of a double salt (e.g., $\left.\mathrm{MgKCl}_{3}\right)$. In our work, we have limited our attention to systems with congruent phase change from solid to liquid.

Additional work relevant to our review was conducted by Gheribi et al, where he used a mesh adaptive direct search (MADS) algorithm in conjunction with FactSage to find all the local liquidus minima of seven chloride salts [49]. He included data for quaternary and higher-order subsystems of these salts. Additional work was conducted in pursuit of useful correlations for thermal conductivity of molten salts [50].

\section{Literature sources}

Although FactSage is a valuable tool and can provide a wealth of data relevant to our work here, there are some gaps within it that require consultation of literature sources. For instance, Schei and Flood's study described the phase equilibria of the $\mathrm{BaCl}_{2}-\mathrm{SrCl}_{2}$ system, and this was used to verify the melting point phase equilibria presented by the FTSalt model, which showed the presence of a phase of unknown state [51]. 
Data for pure component melting points and latent heat of fusion are available in the CRC Handbook of Chemistry and Physics [31]. Other pure component thermophysical properties, including thermal conductivity, specific heat capacity, and radiative properties, can be found in the compilations of Touloukian and coworkers [52-54]. A number of reviews have been conducted addressing the properties of inorganic salts as PCMs [10, $55,56]$. These reviews include relevant properties such as melting point, latent heat of fusion, and eutectic composition for select salt systems. As far as molten salt properties are concerned, the work of Janz and coworkers provides much useful information [57-60]. Phase equilibria data (relevant for mixtures of the salts considered here) are found in numerous works undertaken to analyze and consolidate phase equilibrium diagrams [61-63]; particularly noteworthy is the CD-ROM database compiled by the American Ceramic Society and the U.S. National Institute of Standards and Technology [64].

In addition to the handbooks and compilations mentioned here, many experimental papers of varying breadth can be found in the literature that examine the thermophysical properties of certain chloride salts or their eutectic systems - for example, Clark's work on the $\mathrm{LiCl}-\mathrm{KCl}$ eutectic system [65]. An attempt was made during this review to capture as much of that data as possible, especially with regard to newer experimental work where more precise instrumentation may result in measured values with less experimental error. All reference sources are noted in the thermophysical properties tables presented herein.

FTSalt contains data on all the pure salts except the chlorides of copper $\left(\mathrm{CuCl}, \mathrm{CuCl}_{2}\right)$. For systems involving these compounds, data had to be found in the literature-e.g., as in the case of Etter and Weidenheft's work with $\mathrm{KCl}-\mathrm{CuCl}$ eutectic [66]. An older reference, the work of Sandonnini, was consulted, as well; the eutectic melting point data of other systems was found to compare well with FactSage, so data from this reference are also included here [67]. For the $\mathrm{CuCl}-\mathrm{CsCl}$ system, the study by Perner and Jindra was used [68]. Data for the $\mathrm{CuCl}-\mathrm{KCl}$ system were taken from Mirabel [69]. Data for the $\mathrm{CuCl}-\mathrm{CdCl}_{2}$ system were taken 
from Herrmann [70]. Additional data for systems involving $\mathrm{CuCl}$ were taken from Menge [71]. The phase equilibria of the binary system of the two cuprous salts, $\mathrm{CuCl}$ and $\mathrm{CuCl}_{2}$, were obtained from Fontana et al. [72]. Data for some systems involving $\mathrm{CuCl}_{2}$ as a component were taken from Korzhukov and Kabonin [73].

Also, FactSage lacked information on a number of systems involving $\mathrm{CoCl}_{2}$ and other transition metal chlorides. Seifert was consulted to elucidate many of these systems [74]. Also, studies by Ferrari were used $[75,76]$. Data related to the $\mathrm{CsCl}-\mathrm{CdCl}_{2}$ and $\mathrm{KCl}-\mathrm{CdCl}_{2}$ systems were taken from the study by Dergunov [77]. Data for the system of $\mathrm{CdCl}_{2}-\mathrm{PbCl}_{2}$ were obtained from Koerber and Oelsen [78]. Additional data for $\mathrm{CdCl}_{2}$ systems were obtained from Seifert et al. [79]. Some data for systems involving $\mathrm{CrCl}_{3}$ were taken from Korshunov and Raskin [80]; additional data were taken from Efimov and Pitirimov and Vasilkova et al. [81, 82]. Data for the $\mathrm{CsCl}-\mathrm{FeCl}_{2}$ system were taken from Seifert and Klatyk [83]. For the $\mathrm{CsCl}-\mathrm{PbCl} 2$ system, the data of Bergman and Maslennikova were used [84]. The data for the $\mathrm{LiCl}-\mathrm{NiCl}_{2}$ system were taken from the study by Golubeva and Bergman [85]. Lastly, data for the system $\mathrm{LiCl}-\mathrm{PbCl}_{2}$ were taken from Bukhalova and Aleshkina [86].

\section{PURE CHLORIDE SALTS}

There are numerous chlorides which may be considered as TES media. The general categories into which these materials fall are chlorides of alkali metals, alkaline earth metals, transition metals, $p$-block metals, and rare earth metals [15]. For the purposes of this study, we limit ourselves to salts of higher melting temperatures - that is, greater than $400^{\circ} \mathrm{C}$ (ferric chloride, $\mathrm{FeCl}_{3}$, for instance, would be neglected, as its melting temperature is $307.6^{\circ} \mathrm{C}$ [31]). When combined in eutectic mixtures, the resulting salt systems may melt at temperatures lower than $400^{\circ} \mathrm{C}$; it is anticipated that these materials may still find use at elevated temperature as fused salt sensible storage media (e.g., as "solar salt," the eutectic of $\mathrm{KNO}_{3}$ and $\mathrm{NaNO}_{3}$, is used 
currently for dual tank storage in solar power plants [5]). Moreover, many of the pure salts considered exhibited costs well in excess of those of the preponderance of the other candidate salts (for example, chlorides of rare earth metals); as such, salts with costs on the order of $\$ 1000 / \mathrm{kg}$ or more were also excluded during this preliminary screening.

The results of this screening are shown in Table 1 . The melting temperatures and enthalpy change of fusion for these substances were obtained from the same reference data compilation [31]; further, they were cross-referenced with other databases to assure validity (e.g., $[40,62,87])$. Costs were obtained by taking the lowest "bulk" price among the aggregate vendors on the chemical identification and supply website, SciFinder [18]. Prices reflect quotes obtained over the approximate period of October - December 2014. A variety of different purities were available, so prices for purities less than $95 \%$ were excluded from consideration (lower purity salts would give less predictable / reliable thermophysical properties). It is worthwhile to note here that, even at purities of $95 \%$ and greater, impurities in the "as-received" salts may hinder the long-term performance of the TES unit utilizing these materials. As such, it may be necessary to pretreat the as received salts to remove or precipitate impurities prior to implementation [11]. For example, it was necessary to thermally treat the "solar salt" $\left(\mathrm{KNO}_{3}-\mathrm{NaNO}_{3}\right.$ eutectic) working fluid in order to eliminate $\mathrm{Mg}\left(\mathrm{NO}_{3}\right)_{2}$ impurities at the Solar Two molten salt power tower installation [4].

The latent heat of these pure materials has been plotted with respect to their costs, and this plot is shown here as Figure 2 [15]. From this depiction, a distinct region of high latent heat / low cost materials that would be ideal as storage media for LHTES can be clearly seen. Materials with greater cost and lower latent heat, of course, would not be recommended for use as LHTES media. In between, there are materials of less certain applicability-either relatively inexpensive but low in latent heat (e.g., $\mathrm{BaCl}_{2}$ ), or high in latent heat but also expensive (e.g., $\mathrm{CoCl}_{2}$ ). Any of the materials shown in this figure (or mixtures thereof) may be used as 
fused salt sensible heat storage media, depending on other thermophysical properties (melting temperature, density, specific heat, etc.) and their chemical stability.

The melting point, latent heat, specific heat capacity, and thermal conductivity for the pure salts obtained from the screening process are listed in Table 1, along with cost data obtained from the various vendors. As with our preliminary study, costs were reported in two ways: on a mass basis, which is more appropriate for cost comparison of sensible heat storage media, and on a latent heat basis, which is appropriate for cost comparison of LHTES media [15].

Next, we consider the binary eutectic mixtures of the pure salts listed in Table 1. The FactSage database, FTSalt has data for most of the systems considered here. For those that were not in the FTSalt database, data were obtained directly from the literature.

As with the pure salts, the latent heat of fusion is a desired quantity to aid in the selection of LHTES storage media. The latent heat of fusion can be estimated based on entropy additivity of its pure component salts [39]. This approximation can be articulated as follows [9].

$$
\Delta H_{f u s, a p p}=T_{m} \sum_{i} \frac{x_{i} \Delta H_{f u s, i}}{T_{m, i}}
$$

This equation can allow for direct comparison among all the individual salt mixtures, for many of whom direct latent heat data are unavailable [15]. The estimates obtained from this expression, however, are rough approximations [33]. If we take, for example, the binary eutectic system, $\mathrm{KCl}-\mathrm{NaCl}$, we find a latent heat of fusion reported in various studies as $273 \mathrm{~J} / \mathrm{g}$ [88], $278 \mathrm{~J} / \mathrm{g}$ [89], and $282 \mathrm{~J} / \mathrm{g}$ [19]. Equation (1) yields a value of $360 \mathrm{~J} / \mathrm{g}$ [15]. So, although this equation may be used for approximate comparisons among salt systems for which no latent heat data are available, it is important to remember that it is approximate. 
It is possible to estimate the latent heat capacity (i.e., the enthalpy change of fusion) using the FactSage thermodynamic model. In the case of $\mathrm{KCl}-\mathrm{NaCl}$, for instance, it predicts an enthalpy of fusion of 306 $\mathrm{J} / \mathrm{g}$ [19]. In the experience of the authors, it tends to exceed the experimental values in the literature in its estimations. A possible reason for this is as follows [41]. Often in the literature, the specific heat capacity in the solid phase is reported as increasing sharply as the temperature increases in approach of the melting point. Some of this may be attributed to experimental method (e.g., in the case of differential scanning calorimetry), but there is a physical basis, as well: pre-melting effects, vacancies, etc. The FactSage model does not incorporate this effect, and so it can overestimate the enthalpy of fusion.

For this study, Equation (1) is used to estimate latent heat. While it is an approximation, it is useful for making comparisons among all the systems considered, even those which were not found in the FactSage databse.

\section{RADIATIVE PROPERTIES}

The chloride salt systems studied in the paper are particularly useful for TES at higher temperatures. At sufficiently high temperature, radiative transfer becomes a major mode of heat transfer. For the temperatures considered here (approximately $1000^{\circ} \mathrm{C}$ or less), the bulk of this radiation is in the infrared. Moreover, if the molten salt is to be employed as the absorbing fluid in the receiver, information regarding its radiative properties in the ultraviolet and visible regions of the spectrum would be important for modeling solar absorption.

Radiative properties data, unfortunately, are not available for every system considered here. Data for selected pure chloride salts are obtained from the thermophysical properties compilation of Touloukian et al [54]; they are presented in Figure 3. Specifically, the normal spectral transmittance (measured at room 
temperature) is presented for $\mathrm{CuCl}, \mathrm{KCl}, \mathrm{NaCl}$, and $\mathrm{PbCl}_{2}$. The samples in these cases were single, polished crystals; in practice, these materials will likely experience additional attenuation due to impurities, fractures, grain boundaries, etc. Also, since the measurements were made at room temperature, one can expect the near- to mid-infrared absorption to rise with temperature, especially if lattice defects or dopants are present within the crystal [90]. Nonetheless, we gain a general picture of these materials' properties from the plotted normal spectral transmittance. The chloride salt data shown with the radiative properties of ionic crystals, having one or more absorption bands in the mid- to far-infrared (Reststrahlen absorption) and several absorption bands near the ultraviolet (electronic excitation), as described by the Lorentz model [90].

The question of radiative properties in the context of LHTES has drawn much interest recently. Myers et al studied molten chloride salt radiative properties with a multi-window reflectance spectrometer technique, showing increased radiative absorption in pure $\mathrm{KCl}-\mathrm{NaCl}$ eutectic salt upon addition of small amounts of transition metal chlorides $[14,19]$. While specifically focused on LHTES, there are implications for sensible heat storage, as well, especially in the molten salt is to work as an absorbing fluid in a solar field. Drotning proposed such a scheme, which involved incorporation of oxide particles into nitrate salts to increase UV/visible absorption-nitrate salts are more or less transparent in the visible [91, 92]. A relevant study was performed by Halmann and Zuckerman, who examined the stability of light absorbing oxide particles in molten nitrate salt [93]. Arai and coworkers extended this idea to an organic absorbing fluid [94]. In each of these cases, though, the goal was absorption of (visible) solar radiation. In the case of chloride salts, there is potential for infrared thermal radiation absorption though the selection of appropriate additives; this could lead to increased heat transfer rates via radiative exchange between the containment and the salt(s) as a participating medium, a relatively unexplored phenomenon. 
To that end Archibold and coworkers conducted extensive numerical simulation of encapsulated inorganic salt based PCMs, including a result involving solidification of nitrate in a spherical shell which showed including radiative heat transfer effects decreased the solidification time by as much as $17 \%$ relative to the conduction / convection only case [95]. Additional work involved the solidification of $\mathrm{NaCl}$ in a similar geometry [96]. Other work in the numerical side of radiative transfer in molten salt PCMs was conducted by Pirasaci and Goswami [97]. They analyzed $\mathrm{NaCl}-\mathrm{MgCl}_{2}$ eutectic as a LHTES medium for the generation of steam.

\section{CONTAINMENT MATERIALS / METHODS}

High temperature conditions $\left(>400^{\circ} \mathrm{C}\right)$, cyclic thermal stress, and corrosive TES media present a unique challenge to the material selection process. Corrosion is a major consideration at these temperatures. According to a survey conducted by Rahmel, chloride melts facilitate corrosion of steels in air [98]. The ternary chloride system of $\mathrm{NaCl}-\mathrm{BaCl}_{2}-\mathrm{MgCl}_{2}$ was studied at 500 and $600^{\circ} \mathrm{C}$ for a variety of steels; significant corrosion was observed, with the best corrosion resistance seen in the $20 \mathrm{Cr}-32 \mathrm{Ni}$ steel. The corrosion rate of the nickelbased alloys was found to increase with increasing partial pressure of oxygen, suggesting that diffusion of oxygen through the melt to the metal's surface was the rate-limiting step. Other work showed that water vapor, too, could play a role in the corrosion process, with the presence of water vapor increasing the corrosion of iron by the $\mathrm{KCl}-\mathrm{LiCl}$ eutectic melt.

Numerous studies have been conducted addressing the solubility of metal oxides in fused chloride melts. Studies such as these are of relevance here because the dissolution of any protective oxide layer on metal containment materials causes the cumulative corrosion of those materials -i.e., as seen in the conversion of chromium (III) oxide to the chromate ion in chloride melt in the presence of air [98]. With the 
protective oxide layer removed, corrosion continues unchecked. Esin and Lyumkis investigated the solubility of various metal oxides in fused chloride salts [99]. They demonstrated dissolution of nickel and cobalt at in a chloride melt at $800^{\circ} \mathrm{C}$. They observed stratification between a metal rich layer (concentrations between 2 and $20 \mathrm{wt} \%$ ) and a metal poor layer (concentrations on the order of $0.1 \mathrm{wt} \%$ ). It is interesting to note that even this lower concentration can impact the thermophysical properties of the bulk fused salt-most notably, radiative absorption.

The demonstration of nick oxide solubility is especially pertinent, because nickel-based alloys are frequently employed in corrosive applications. Various studies discuss the role of specialty alloys for corrosive applications. Vignarooban et al reported corrosion rates for various Hastelloys in $\mathrm{NaCl}-\mathrm{KCl}^{-} \mathrm{ZnCl}{ }_{2}$ molten salt mixtures up to $500^{\circ} \mathrm{C}[100]$. However, containment materials must not only protect against corrosion, but must also be cost-effective. While some nickel alloys may withstand these corrosive conditions, their selection is hindered by their high costs (4 times as high as stainless steel alloys [26]). Hence, steel or steel-based alloys could prove to be important contributors towards containment of the chloride based TES systems.

It has been found that certain elements like $\mathrm{Cr}$ and $\mathrm{Ni}$ are conducive to improving corrosion resistance of low carbon microalloying steel [101]. Moreover, corrosion rates increase with increasing temperatures [102]. Hiramatsu et al. presented the effects of alloying elements of stainless steels on $\mathrm{NaCl}$ induced corrosion in a temperature range of $450^{\circ} \mathrm{C}$ to $750^{\circ} \mathrm{C}$. Austenitic stainless steels displayed better results than ferritic stainless steels [102]. SEM/EDXA analysis was conducted by Lehmusto et al to study the effect of solid $\mathrm{KCl}$ on superheater steels at elevated temperatures [103]. Nickel-based alloy 625-type steel was found to be more durable in terms of corrosion resistance as compared to ferritic 10CrMo-type steel. In case of the alloy 625 type steel, the thick oxide layer predominantly comprised of nickel oxide in the presence of $\mathrm{KCl}$. Furthermore, a comprehensive analysis of various Fe-Cr-Ni alloys was conducted by Evans et al [104]. This study concluded 
that diffusion of $\mathrm{Cr}$ ions in the $\mathrm{Cr}_{2} \mathrm{O}_{3}$ scale was the rate controlling step in the temperature range of $700^{\circ} \mathrm{C}$ to $1100^{\circ} \mathrm{C}$. The role of chlorides in hot corrosion of high alloy stainless steels was studied by Mohanty et al [105]. The authors concluded that thermal cycling, when superimposed on hot corrosion, caused spallation of the oxide layer while cooling.

Corrosion protection afforded by various protective coatings has also been evaluated in various studies. Shankar et al compared the performance of yttria-stabilized zirconia coating on 316L SS with respect to uncoated $316 \mathrm{LSS}[106]$. The testing was carried out at elevated temperatures of $600^{\circ} \mathrm{C}$ and the coating was found to be instrumental in providing improved corrosion resistance. Uusitalo et al discussed results of experimental studies of boiler steels and protective coatings at high temperatures [107]. The coatings evaluated were high velocity oxy-fuel (HVOF) coatings, laser cladding, and diffusion chromized steel. In addition, two boiler steels were also analyzed. The performance of nickel-based high chromium coatings was found to be satisfactory.

In addition to developing new alloys and protective coatings, other techniques employed to improve the corrosion resistance of cost effective stainless steel based alloys include shot peening, cladding and internal insulation approach [26]. Shot peening is employed to change the grain size and the structure of the alloy at the surface to improve its corrosion resistance. Smaller grain size provides a larger surface area for formation of passivating layers [108].

Cladding is a method bonding thin protective layers to a substrate through roll welding, explosive welding or laser application. Internal insulation approach employs thermally insulating refractory bricks as internal liner to the storage tank. Inexpensive insulation materials make this an economically attractive option. This approach has been employed in coal gasification industries [109]. 
High temperature chlorides may require non-metallic containment, as most metals would be prone to corrosion in the presence of these materials and even small quantities of oxygen and/or moisture. One could justifiably predict that ceramic materials would be necessary for these uses, and in this case the importance of radiative transfer is amplified, for two reasons. On the one hand, ceramics are significantly less conductive than metals; on the other, metals tend to be less emissive than ceramics.

\section{COST COMPARISON}

In Figure 4, the cost per kg of the binary salt eutectic mixtures is plotted against melting temperature. The systems are labeled with their numbers as listed in Table 2. Also included for reference are cost data for the nitrate salts, $\mathrm{NaNO}_{3}$ and $\mathrm{KNO}_{3}$, which are now commonly used for sensible storage media. From this plot, it is clear which systems are preferable in terms of cost at each temperature of interest; in general, the systems involving the chlorides of sodium, potassium, and magnesium tend to be less expensive, as well as some systems involving chlorides of barium and calcium. In Figure 5, the cost per kJ latent heat (estimated) is plotted against melting temperature for the same binary systems (again, numbered as in Table 2). While the grouping of materials is qualitatively similar to that shown in Figure 4, differences that arise are illustrative of the different selection process required for latent heat media as opposed to that required for sensible heat media. For instance, it can be seen in Figure 5 that system $9\left(\mathrm{BaCl}_{2}-\mathrm{NaCl}\right)$ is more expensive than system 17 $\left(\mathrm{CaCl}_{2}-\mathrm{KCl}\right)$ on the basis of latent heat cost, although it is cheaper on a mass basis, as shown in Figure 4. Last, we present all the chloride salt systems (pure or eutectic) that fall below $\$ 0.20$ per kJ latent heat (Figure 6). These materials show most promise as PCMs in a LHTES arrangement. It is clear from the plot that there are a wealth of salt systems which can cover the range of approximately $400-800^{\circ} \mathrm{C}$ (e.g., in a cascade latent heat storage system [110]). Based on this observation, it seems that more expensive salts (e.g., 
fluorides) or metals may be needed for latent heat storage media at higher temperatures; alternatively, sensible heat storage could be explored.

As an illustration of the information that can be gleaned from these charts, consider a cascaded latent heat system designed to heat a working fluid from 400 to $540^{\circ} \mathrm{C}$ [15]. Consulting Figure 6 , we see that the 90 $\rightarrow 91 \rightarrow 6 \rightarrow 7$ cascade - that is, two eutectic mixtures of $\mathrm{KCl}-\mathrm{MgCl}_{2}$, followed by $\mathrm{BaCl}_{2}-\mathrm{LiCl}$ and $\mathrm{BaCl}_{2}-\mathrm{MgCl}_{2}-$ provides a suitable configuration with an approximate $20^{\circ} \mathrm{C}$ approach or greater and approximately $50^{\circ} \mathrm{C}$ separation between each PCM melting point.

\section{CONCLUSIONS / FUTURE WORK}

Inorganic salts are promising as TES media to increase dispatchability and capacity factor of CSP plants. Nitrate salts especially have found widespread use in this context. Chloride salts, however, have received less attention. This paper proposes various chloride salt systems for use in high temperature $\left(>400^{\circ} \mathrm{C}\right)$ solar power plants, either as working fluid, sensible heat storage media, or latent heat storage media (i.e., PCMs). A group of 17 pure chloride salts was obtained from a preliminary screening process based on cost and melting temperature. An additional 116 systems, taken from the binary eutectic systems of the pure salts, were studied. Where possible, the systems were modeled using the thermodynamic database software, FactSage; otherwise, data were obtained from the literature regarding their melting points and phase equilibria. A cost comparison was performed for the systems in application as sensible heat storage media or latent heat storage media.

Lack of measured properties data for many of these systems is a distinct challenge, and future work is planned to address this problem. Here, a relatively approximate means was used to estimate latent heat. However, the authors are currently investigating the accuracy and reliability of the FactSage model to 
calculate latent heat, with the hopes that it may provide better estimates. The specific heat data calculated by FactSage are also of interest. In either case, a rigorous comparison of calculated values with experimental values taken from the literature is required.

One thermophysical property that should also be taken into account is the thermal conductivity of the salt systems. The liquid phase conductivity is of some interest, but more important is the solid phase conductivity, which can limit the discharging process of a LHTES unit. This is due to the tendency of the solidification of these materials to be effectively conduction limited.

Finally, potential downsides of these materials (containment compatibility, long-term thermal stability) need to be studied in greater detail. Nonetheless, it is expected that chloride salts in general can find use in high temperature TES applications in the near future.

\section{ACKNOWLEDGMENT}

This research is based in part upon work supported by the US-India Partnership to Advance Clean EnergyResearch (PACE-R) for the Solar Energy Research Institute for India and the U.S. (SERIIUS) funded jointly by the U.S. Department of Energy subcontract DE AC36-08G028308 (Office of Science, Office of Basic Energy Sciences, and Energy Efficiency and Renewable Energy, Solar Energy Technology Program, with support from the Office of International Affairs) and the Government of India subcontract IUSSTF/JCERDC-SERIIUS/2012 dated $22^{\text {nd }}$ Nov. 2012. The authors would also like to thank colleagues and staff at the Clean Energy Research Center at the University of South Florida for their assistance and advice. 
Applied Thermal Engineering

\section{NOMENCLATURE}

$C_{p} \quad$ Specific heat capacity

$T_{m} \quad$ Melting temperature

$x_{i} \quad$ Mole fraction of component, $i$

$\Delta H_{f u s, i} \quad$ Latent heat of fusion of component, $i$

$\Delta H_{\text {fus,app }} \quad$ Approximate latent heat of fusion of a eutectic system, as calculated by Equation (1) 


\section{REFERENCES}

[1] R. Margolis, C. Coggeshall, and J. Zuboy, "Sunshot Vision Study," US Dept. of Energy, 2012.

[2] M. L. Yang, X. X. Yang, X. P. Yang, and J. Ding, "Heat transfer enhancement and performance of the molten salt receiver of a solar power tower," Applied Energy, vol. 87, pp. 2808-2811, Sep 2010.

[3] A. Rovira, M. J. Montes, M. Valdes, and J. M. Martinez-Val, "Energy management in solar thermal power plants with double thermal storage system and subdivided solar field," Applied Energy, vol. 88, pp. 4055-4066, Nov 2011.

[4] H. E. Reilly and G. J. Kolb, "An evaluation of molten-salt power towers including results of the solar two project," Sandia National Labs., Albuquerque, NM (US); Sandia National Labs., Livermore, CA (US)2001.

[5] U. Herrmann and D. W. Kearney, "Survey of thermal energy storage for parabolic trough power plants," Journal of Solar Energy Engineering-Transactions of the ASME, vol. 124, pp. 145-152, May 2002.

[6] K. H. Stem, "High temperature properties and decomposition of inorganic salts Part 3. Nitrates and nitrites," J. Phys. Chem. Ref. Data, vol. 1, 1972.

[7] Y. Hoshino, T. Utsunomiya, and O. Abe, "The Thermal-Decomposition of Sodium-Nitrate and the Effects of Several Oxides on the Decomposition," Bulletin of the Chemical Society of Japan, vol. 54, pp. 13851391, 1981.

[8] B. Hoffschmidt, F. M. Tellez, A. Valverde, J. Fernandez, and V. Fernandez, "Performance evaluation of the 200-kW(th) HiTRec-Il open volumetric air receiver," Journal of Solar Energy Engineering, vol. 125, pp. 87-94, Feb 2003.

[9] N. Lior, P. Ayyaswamy, J. Oleary, K. Kauffman, H. Yeh, and H. Lorsch, "Thermal energy storage considerations for solar-thermal power generation," in 11th Intersociety Energy Conversion Engineering Conference, 1976, pp. 613-622.

[10] A. Hoshi, D. R. Mills, A. Bittar, and T. S. Saitoh, "Screening of high melting point phase change materials (PCM) in solar thermal concentrating technology based on CLFR," Solar Energy, vol. 79, pp. 332-339, 2005.

[11] A. Ferrara, R. Haslett, and J. Joyce, "Molten salt thermal energy storage for utility peaking loads," in 12th Intersociety Energy Conversion Engineering Conference, 1977, pp. 547-554.

[12] M. Chase Jr, C. Davies, J. Downey Jr, D. Frurip, R. McDonald, and A. Syveraud, "JANAF thermodynamic tables," J. Phys. Chem. Ref. Data, vol. 14, 1985.

[13] C. Robelin, P. Chartrand, and A. D. Pelton, "Thermodynamic evaluation and optimization of the ( $\mathrm{MgCl}$ $2+\mathrm{CaCl} 2+\mathrm{MnCl} 2+\mathrm{FeCl} 2+\mathrm{CoCl} 2+\mathrm{NiCl} 2$ ) system," The Journal of Chemical Thermodynamics, vol. 36, pp. 793-808, 2004. 
[14] P. D. Myers, Jr., "Additives for heat transfer enhancement in high temperature thermal energy storage media: Selection and characterization," Ph.D., Chemical Engineering, University of South Florida, 2015.

[15] P. D. Myers, Jr., A. Bhardwaj, D. Y. Goswami, and E. Stefanakos, "Chloride Salt Systems for High Temperature Thermal Energy Storage: Properties and Applications," in ASME 2015 9th International Conference on Energy Sustainability collocated with the ASME 2015 Power Conference, the ASME 2015 13th International Conference on Fuel Cell Science, Engineering and Technology, and the ASME 2015 Nuclear Forum, 2015, pp. V001T03A003-V001T03A003.

[16] C. Bale, P. Chartrand, S. Degterov, G. Eriksson, K. Hack, R. B. Mahfoud, et al., "FactSage thermochemical software and databases," Calphad, vol. 26, pp. 189-228, 2002.

[17] C. Bale, E. Bélisle, P. Chartrand, S. Decterov, G. Eriksson, K. Hack, et al., "FactSage thermochemical software and databases-recent developments," Calphad, vol. 33, pp. 295-311, 2009.

[18] (Oct - Dec). Available: http://scifinder.cas.org

[19] P. D. Myers, Jr., D. Y. Goswami, and E. Stefanakos, "Molten salt spectroscopy for quantification of radiative absorption in novel metal chloride-enhanced thermal storage media," Journal of Solar Energy Engineering, vol. 137, p. 041002, 2015.

[20] T. M. I. Mahlia, T. J. Saktisandan, A. Jannifar, M. H. Hasan, and H. S. C. Matseelar, "A review of available methods and development on energy storage; technology update," Renewable \& Sustainable Energy Reviews, vol. 33, pp. 532-545, May 2014.

[21] S. Kuravi, J. Trahan, D. Y. Goswami, M. M. Rahman, and E. K. Stefanakos, "Thermal energy storage technologies and systems for concentrating solar power plants," Progress in Energy and Combustion Science, vol. 39, pp. 285-319, Aug 2013.

[22] D. Barlev, R. Vidu, and P. Stroeve, "Innovation in concentrated solar power," Solar Energy Materials and Solar Cells, vol. 95, pp. 2703-2725, Oct 2011.

[23] D. Y. Goswami, F. Kreith, and J. F. Kreider, Principles of solar engineering, 2nd ed. Philadelphia ; London: Taylor \& Francis, 2000.

[24] A. F. Regin, S. C. Solanki, and J. S. Saini, "Heat transfer characteristics of thermal energy storage system using PCM capsules: A review," Renewable \& Sustainable Energy Reviews, vol. 12, pp. 2438-2458, Dec 2008.

[25] H. Michels and R. Pitz-Paal, "Cascaded latent heat storage for parabolic trough solar power plants," Solar Energy, vol. 81, pp. 829-837, 2007.

[26] J. Stekli, L. Irwin, and R. Pitchumani, "Technical Challenges and Opportunities for Concentrating Solar Power With Thermal Energy Storage," Journal of Thermal Science and Engineering Applications, vol. 5, p. 021011, 2013. 
[27] A. Abhat, "Low-Temperature Latent-Heat Thermal-Energy Storage - Heat-Storage Materials," Solar Energy, vol. 30, pp. 313-332, 1983.

[28] B. Cardenas and N. Leon, "High temperature latent heat thermal energy storage: Phase change materials, design considerations and performance enhancement techniques," Renewable \& Sustainable Energy Reviews, vol. 27, pp. 724-737, Nov 2013.

[29] U. Herrmann, B. Kelly, and H. Price, "Two-tank molten salt storage for parabolic trough solar power plants," Energy, vol. 29, pp. 883-893, Apr-May 2004.

[30] G. J. Kolb, "Evaluation of Annual Performance of 2-Tank and Thermocline Thermal Storage Systems for Trough Plants," Journal of Solar Energy Engineering-Transactions of the ASME, vol. 133, Aug 2011.

[31] D. R. Lide and H. P. R. Frederikse, CRC handbook of chemistry and physics : a ready-reference book of chemical and physical data, 76th ed / ed. Boca Raton, Fla. ; London: CRC, 1995.

[32] J. Clayton, "Research on energy storage for solar thermal conversion," Final Report Xerox ElectroOptical Systems, Pasadena, CA., vol. 1, 1978.

[33] M. Kamimoto, T. Tanaka, T. Tani, and T. Horigome, "Investigation of Nitrate Salts for Solar Latent HeatStorage," Solar Energy, vol. 24, pp. 581-587, 1980.

[34] Y. Marcus, "Thermal Energy Storage," in Molten Salt Technology, D. G. Lovering, Ed., New York: Plenum Press, 1982, pp. $457-498$.

[35] D. Kearney, U. Herrmann, P. Nava, P. Kelly, R. Mahoney, J. Pacheco, et al., "Assessment of a molten salt heat transfer fluid in a parabolic trough solar field," Journal of Solar Energy Engineering, vol. 125, pp. 170-176, May 2003.

[36] L. Radosevich and C. Wyman, "Thermal energy storage development for solar electrical power and process heat applications," Journal of Solar Energy Engineering, vol. 105, pp. 111-118, 1983.

[37] T. Tanaka, "Solar thermal electric power systems in Japan," Solar Energy, vol. 25, pp. 97-104, 1980.

[38] H. Venkatesetty and R. LeFrois, "Thermal energy storage for solar power plants," in 11th Intersociety Energy Conversion Engineering Conference, 1976, pp. 606-612.

[39] Y. Abe, M. Kamimoto, Y. Takahashi, R. Sakamoto, K. Kanari, and T. Ozawa, "Peak load coverage by molten salts latent thermal storage," in Intersociety energy conversion engineering conference. 19, 1984, pp. 1114-1119.

[40] C. W. Bale, P. Chartrand, S. A. Decterov, G. Eriksson, K. Hack, R. B. Mahfoud, et al., "FactSage Thermochemical Software and Databases," Calphad Journal, vol. 62, pp. 189-228, 2002.

[41] P. Chartrand, Personal communication, January 28, 2015. 
[42] A. D. Pelton and P. Chartrand, "Thermodynamic evaluation and optimization of the LiCl- $\mathrm{NaCl}-\mathrm{KCl}-\mathrm{RbCl}-$ $\mathrm{CsCl}-\mathrm{MgCl} 2-\mathrm{CaCl} 2$ system using the modified quasi-chemical model," Metallurgical and Materials transactions A, vol. 32, pp. 1361-1383, 2001.

[43] J. Coughlin, "High-temperature heat content of nickel chloride," Journal of the American Chemical Society, vol. 73, pp. 5314-5315, 1951.

[44] C. Robelin, P. Chartrand, and A. D. Pelton, "Thermodynamic evaluation and optimization of the ( $\mathrm{NaCl}+$ $\mathrm{KCl}+\mathrm{AlCl} 3$ ) system," The Journal of Chemical Thermodynamics, vol. 36, pp. 683-699, 2004.

[45] C. Robelin, P. Chartrand, and A. D. Pelton, "Thermodynamic evaluation and optimization of the ( $\mathrm{NaCl}+$ $\mathrm{KCl}+\mathrm{MgCl} 2+\mathrm{CaCl} 2+\mathrm{MnCl} 2+\mathrm{FeCl} 2+\mathrm{CoCl} 2+\mathrm{NiCl} 2)$ system," The Journal of Chemical Thermodynamics, vol. 36, pp. 809-828, 2004.

[46] C. Robelin, P. Chartrand, and G. Eriksson, "A density model for multicomponent liquids based on the modified quasichemical model: Application to the $\mathrm{NaCl}-\mathrm{KCl}-\mathrm{MgCl} 2-\mathrm{CaCl} 2$ system," Metallurgical and Materials Transactions B, vol. 38, pp. 869-879, 2007.

[47] C. Robelin and P. Chartrand, "Thermodynamic evaluation and optimization of the $(\mathrm{NaCl}+\mathrm{KCl}+\mathrm{MgCl} 2+$ $\mathrm{CaCl} 2+\mathrm{ZnCl} 2$ ) system," The Journal of Chemical Thermodynamics, vol. 43, pp. 377-391, 2011.

[48] J. Gomez, "High-Temperature Phase Change Materials (PCM) Candidates for Thermal Energy Storage (TES) Applications," National Renewable Energy Laboratory (NREL), Golden, CO2011.

[49] A. E. Gheribi, C. Robelin, S. Le Digabel, C. Audet, and A. D. Pelton, "Calculating all local minima on liquidus surfaces using the factsage software and databases and the mesh adaptive direct search algorithm," The Journal of Chemical Thermodynamics, vol. 43, pp. 1323-1330, 2011.

[50] A. E. Gheribi, J. A. Torres, and P. Chartrand, "Recommended values for the thermal conductivity of molten salts between the melting and boiling points," Solar Energy Materials and Solar Cells, vol. 126, pp. 11-25, 2014.

[51] A. Schei and H. Flood, "The Phase Diagram of the System SrCl2-BaCl2," Acta Chemica Scandinavica, vol. 14, pp. 2067-2070, 1960.

[52] Y. S. Touloukian, R. W. Powell, C. Y. Ho, and P. G. Klemens, "Thermophysical Properties of Matter-the TPRC Data Series. Volume 2. Thermal conductivity: Nonmetallic Solids," IFI/Plenum, New York, 1970.

[53] Y. S. Touloukian and E. H. Buyco, "Thermophysical Properties of Matter-the TPRC Data Series. Volume 5. Specific Heat-Nonmetallic Solids," DTIC Document1970.

[54] Y. S. Touloukian and D. P. DeWitt, "Thermophysical Properties of Matter-the TPRC Data Series. Volume 8. Thermal Radiative Properties-Nonmetallic Solids," DTIC Document1972.

[55] M. M. Kenisarin, "High-temperature phase change materials for thermal energy storage," Renewable \& Sustainable Energy Reviews, vol. 14, pp. 955-970, Apr 2010. 
[56] B. Zalba, J. M. Marin, L. F. Cabeza, and H. Mehling, "Review on thermal energy storage with phase change: materials, heat transfer analysis and applications," Applied Thermal Engineering, vol. 23, pp. 251-283, Feb 2003.

[57] G. J. Janz, Molten salts handbook. New York,: Academic Press, 1967.

[58] G. J. Janz, C. B. Allen, N. Bansal, R. Murphy, and R. Tomkins, "Physical properties data compilations relevant to energy storage, 2 . Molten salts: Data on single and multi-component salt systems," NASA STI/Recon Technical Report N, vol. 80, p. 10643, 1979.

[59] G. J. Janz, C. B. Allen, J. R. Downey, and R. Tomkins, "Physical properties data compilations relevant to energy storage, 1. Molten salts: Eutectic data," NASA STI/Recon Technical Report N, vol. 78, p. 31589, 1978.

[60] G. J. Janz and R. Tomkins, "Physical Properties Data Compilations Relevant to Energy Storage, 4. Molten Salts: Data on Additional Single and Multicomponent Salt Systems.(Pamphlet)," National Bureau of Standards, 861, p. 1981, 1981.

[61] J. Sangster and A. D. Pelton, "Phase-Diagrams and Thermodynamic Properties of the 70 Binary AlkaliHalide Systems Having Common Ions," Journal of Physical and Chemical Reference Data, vol. 16, pp. 509-561, 1987.

[62] V. I. Posypajko, E. A. Alekseeva, and H. B. Bell, Phase equilibria in binary halides. New York: IFI/Plenum, 1987.

[63] E. M. Levin, Phase diagrams for ceramists. Columbus, Ohio,: American Ceramic Society, 1956.

[64] A.-N. P. E. Diagram, "CD-ROM Database," ed: Version, 2005.

[65] R. P. Clark, "Heats of Fusion and Heat-Capacities of Lithium Chloride Potassium Chloride Eutectic and Potassium-Nitrate," Journal of Chemical and Engineering Data, vol. 18, pp. 67-70, 1973.

[66] D. Etter and C. Wiedenheft, "The study of $\mathrm{KCl}-\mathrm{CuCl}$ eutectic fused salt as a potential intermediate temperature heat transfer and storage medium," Solar Energy Materials, vol. 2, pp. 423-431, 1980.

[67] C. Sandonnini, "Analisi termica di miscele binarie di cloruri di elementi monovalenti e bivalenti," Gazzetta Chimica Italiana, vol. 44, pp. 290 - 386, 1914.

[68] M. Perner and J. Jindra, "PRODUCTION OF CUCI SINGLE CRYSTALS FOR OPTICAL PURPOSES," Growth of Crystals, vol. 7, pp. $270-276,1969$.

[69] P. Mirabel, "DETERMINATION OF LIQUIDS CURVES OF CUCL-KCL AND CUCL-RBCL SYSTEMS," COMPTES RENDUS HEBDOMADAIRES DES SEANCES DE L ACADEMIE DES SCIENCES SERIE C, vol. 272, pp. $534-$ $537,1971$. 
[70] G. Herrmann, "Über die Verbindungsfähigkeit der Chloride von $\mathrm{Cu}, \mathrm{Pb}, \mathrm{Fe}, \mathrm{Zn}$, Sn und Bi und über die Verbindungsfähigkeit der Chloride, Bromide und Jodide von $\mathrm{Cu}$ und $\mathrm{Cd}$ und die Lichtempfindlichkeit ihrer Mischkristalle," Zeitschrift für anorganische Chemie, vol. 71, pp. 257-302, 1911.

[71] O. Menge, "Die binären Systeme von $\mathrm{MgCl} 2$ und $\mathrm{CaCl} 2$ mit den Chloriden der Metalle $\mathrm{K}, \mathrm{Na}, \mathrm{Ag}, \mathrm{Pb}, \mathrm{Cu}$ ', Zn, Sn "und Cd," Zeitschrift für anorganische Chemie, vol. 72, pp. 162-218, 1911.

[72] C. Fontana, E. Gorin, G. Kidder, and C. Meredith, "CHLORINATION OF METHANE WITH COPPER CHLORIDE MELTS. TERNARY SYSTEM, CUCl-CuCl2-KCl, AND ITS EQUILIBRIUM CHLORINE PRESSURES," Industrial \& Engineering Chemistry, vol. 44, pp. 363-368, 1952.

[73] N. G. Korzhukov and Y. B. Kabonin, "Melting Diagrams of the $\mathrm{FeCl} 2-\mathrm{CuCl} 2$ and $\mathrm{CoCl} 2-\mathrm{CuCl} 2 \mathrm{Systems,"}$ Vestn. Mosk. Univer., Ser. 2. Khim., vol. 21, p. 66, 1966.

[74] H. J. Seifert, "Über die Systeme Alkalimetallchlorid/Kobalt (II)-chlorid," Zeitschrift für anorganische und allgemeine Chemie, vol. 307, pp. 137-144, 1961.

[75] A. Ferrari and A. Inganni, "Thermal Analysis of the Systems $\mathrm{SrCl} 2-\mathrm{FeCl} 2, \mathrm{SrCl} 2-\mathrm{CoCl} 2, \mathrm{ZnCl} 2-\mathrm{FeCl} 2$ and ZnCl2-CoCl2," Atti della Reale Accad. dei Lincei, vol. 12, pp. 668 - 675, 1930.

[76] A. Ferrari and C. Colla, Atti della Reale Accad. dei Lincei, vol. 17, pp. 473 - 475, 1933.

[77] E. Dergunov, "Kompleksoobrazovanie Mezhdu Khloridom Kadmiya I Khloridami Shchelochnykh Metallov," Doklady Akademii Nauk SSSR, vol. 64, pp. 517-520, 1949.

[78] F. Körber and W. Oelsen, "Die Gleichgewichte $\mathrm{Pb}+\mathrm{SnCl} 2=\mathrm{PbO} 2+\mathrm{Sn}$ und $\mathrm{Cd}+\mathrm{PbCl} 2==\mathrm{CdCl} 2+\mathrm{Pb}$ im Schmelzfluß. Ein Beitrag zur Frage der Anwendbarkeit des idealenMassenwirkungsgesetzes," Mitt. KWI Eisenforschg. Bd, vol. 14, pp. 119-136, 1932.

[79] H. J. Seifert, G. Thiel, and R. Schmitt, "Thermochemical investigatioons on systems of cadmium chloride and cadmium bromide with alkali metal halides," in Proceedings of the 6th International Conference on Thermal Analysis, Bayreuth, Germany, July 6 - 12, 1980. vol. 2, W. Hemminger, Ed., Basel, Switzerland: Birkaeuser Verlag, 1980, pp. $81-86$.

[80] B. Korshunov and B. Y. Raskin, "INTERACTION OF CHROMIUM (III) CHLORIDE WITH SODIUM, POTASSIUM, AND MAGNESIUM CHLORIDES IN MOLTEN STATE," ZHURNAL NEORGANICHESKOI KHIMII, vol. 7, pp. 1137-1140, 1962.

[81] A. Efimov and B. Pitirimov, "Equilibrium Diagrams of the $\mathrm{CrCl} 3-\mathrm{RbCl}$ and $\mathrm{CrCl} 3-\mathrm{CsCl}$ Systems-Zhur," Neorg. Khim, vol. 8, p. 1042, 1963.

[82] I. Vasilkova, A. Efimov, and B. Pitirimov, "Complex Formation in the $\mathrm{MQ}-\mathrm{CrCl} 3$ System (M is Alkali Metals) Zhur," Neorg. Khim, vol. 9, p. 493, 1964.

[83] H. J. Seifert and K. Klatyk, "Über die Systeme $\mathrm{RbCl} / \mathrm{FeCl} 2$ und $\mathrm{CsCl} / \mathrm{FeCl} 2$," Zeitschrift für anorganische und allgemeine Chemie, vol. 342, pp. 1-9, 1966. 
[84] A. Bergman and G. MASLENNIKOVA, "ADIAGONAL IRREVERSIBLY-RECIPROCAL SYSTEM CONSISTING OF CESIUM AND LEAD CHLORIDES AND SULFATES," ZHURNAL NEORGANICHESKOI KHIMII, vol. 7, pp. 13821386, 1962.

[85] M. Golubeva and A. Bergman, "Ternary mutual system consisting of chlorides and sulfates of potassium and calcium," Zhurnal Obshchei Khimii, vol. 26, pp. 328-338, 1956.

[86] G. Bukhalova and N. Aleshkina, "Interaction of Vanadinite in Melts of Orthovanadates and Chlorides of Li and Pb," Dokl. Akad. Khim Nauk SSSR, vol. 88, pp. 819-820, 1953.

[87] P. Patnaik, Handbook of inorganic chemicals. New York: McGraw-Hill, 2003.

[88] P. Luova and M. Muurinen, Thermodynamic studies on the systems NaCl-KCl and KBr-KI, 1967.

[89] D. R. Waldbaum, "Thermodynamic Mixing Properties of $\mathrm{NaCl}-\mathrm{KCl}$ Liquids," Geochimica et Cosmochimica Acta, vol. 33, pp. 1415-\&, 1969.

[90] M. F. Modest, Radiative heat transfer, 2nd ed. Amsterdam ; Boston: Academic Press, 2003.

[91] W. D. Drotning, Sandia Laboratory., and United States. Energy Research and Development Administration., Optical properties of a solar-absorbing molten salt heat transfer fluid. Albuquerque, N.M.: Sandia Laboratories, 1977.

[92] W. D. Drotning, "Optical-Properties of Solar-Absorbing Oxide Particles Suspended in a Molten-Salt Heat-Transfer Fluid," Solar Energy, vol. 20, pp. 313-319, 1978.

[93] M. Halmann and K. Zuckerman, "Stability of Molten Nitrate Salts Containing Light Absorbing Additives as Solar Flux Absorbers," Solar Energy Materials, vol. 17, pp. 311-318, Jun 1988.

[94] N. Arai, Y. Itaya, and M. Hasatani, "Development of a Volume Heat-Trap Type Solar Collector Using a Fine-Particle Semitransparent Liquid Suspension (Fpss) as a Heat Vehicle and Heat-Storage Medium Unsteady, One-Dimensional Heat-Transfer in a Horizontal Fpss Layer Heated by Thermal-Radiation," Solar Energy, vol. 32, pp. 49-56, 1984.

[95] A. R. Archibold, D. Y. Goswami, M. M. Rahman, and E. K. Stefanakos, "Multi-mode heat transfer analysis during freezing of an encapsulated storage medium," International Journal of Heat and Mass Transfer, vol. 84, pp. 600-609, 2015.

[96] A. R. Archibold, M. M. Rahman, D. Y. Goswami, and E. K. Stefanakos, "The effects of radiative heat transfer during the melting process of a high temperature phase change material confined in a spherical shell," Applied Energy, vol. 138, pp. 675-684, 2015.

[97] T. Pirasaci and D. Y. Goswami, "Influence of design on performance of a latent heat storage system for a direct steam generation power plant," Applied Energy, vol. 162, pp. 644-652, 2016. 
[98] A. Rahmel, "Corrosion," in Molten Salt Technology, D. G. Lovering, Ed., New York: Plenum Press, 1982, pp. $265-283$.

[99] O. A. Esin and S. E. Lyumkis, "Povedenie okislov tyazhelykh metallov v rasplavlennykh khloridakh," Zhurnal Neorganicheskoi Khimii, vol. 2, pp. 1145 - 1148, 1957.

[100] K. Vignarooban, P. Pugazhendhi, C. Tucker, D. Gervasio, and A. Kannan, "Corrosion resistance of Hastelloys in molten metal-chloride heat-transfer fluids for concentrating solar power applications," Solar Energy, vol. 103, pp. 62-69, 2014.

[101] Y. Zhou, J. Chen, Y. Xu, and Z. Liu, "Effects of Cr, Ni and Cu on the Corrosion Behavior of Low Carbon Microalloying Steel in a Cl-Containing Environment," Journal of Materials Science \& Technology, vol. 29, pp. 168-174, 2013.

[102] N. Hiramatsu, Y. Uematsu, T. Tanaka, and M. Kinugasa, "Effects of alloying elements on NaCl-induced hot corrosion of stainless steels," Materials Science and Engineering: A, vol. 120, pp. 319-328, 1989.

[103] J. Lehmusto, P. Yrjas, B.-J. Skrifvars, and M. Hupa, "High temperature corrosion of superheater steels by $\mathrm{KCl}$ and $\mathrm{K}_{2} \mathrm{CO}_{3}$ under dry and wet conditions," Fuel Processing Technology, vol. 104, pp. 253-264, 2012.

[104] H. Evans, D. Hilton, and R. Holm, "Chromium-depleted zones and the oxidation process in stainless steels," Oxidation of metals, vol. 10, pp. 149-161, 1976.

[105] B. P. Mohanty and D. A. Shores, "Role of chlorides in hot corrosion of a cast Fe-Cr-Ni alloy. Part I: experimental studies," Corrosion science, vol. 46, pp. 2893-2907, 2004.

[106] A. R. Shankar and U. K. Mudali, "Corrosion of type 316L stainless steel in molten LiCl-KCl salt," Materials and corrosion, vol. 59, pp. 878-882, 2008.

[107] M. Uusitalo, P. Vuoristo, and T. Mäntylä, "High temperature corrosion of coatings and boiler steels below chlorine-containing salt deposits," Corrosion Science, vol. 46, pp. 1311-1331, 2004.

[108] B. Mordyuk, G. Prokopenko, M. Vasylyev, and M. lefimov, "Effect of structure evolution induced by ultrasonic peening on the corrosion behavior of AISI-321 stainless steel," Materials Science and Engineering: A, vol. 458, pp. 253-261, 2007.

[109] K. Kwong, A. Petty, J. Bennett, R. Krabbe, and H. Thomas, "Wear mechanisms of chromia refractories in slagging gasifiers," International Journal of Applied Ceramic Technology, vol. 4, pp. 503-513, 2007.

[110] T. Watanabe, H. Kikuchi, and A. Kanzawa, "Enhancement of Charging and Discharging Rates in a LatentHeat Storage-System by Use of PCM with Different Melting Temperatures," Heat Recovery Systems \& Chp, vol. 13, pp. 57-66, Jan 1993. 


\section{Figure Captions List}

Fig. $1 \quad$ Generalized phase change process.

Fig. 2 Latent heat plotted against cost for the pure salts considered in this study.

Fig. 3 Normal spectral transmittance for select pure chloride salts, taken from Touloukian[54].

Fig. 4 Cost per kg (e.g., sensible storage application) of salt systems at various temperatures (as numbered in Table 2).

Fig. 5 Cost per kJ (e.g., latent storage application) of salts systems at various temperatures (as numbered in Table 2).

Fig. 6 Pure salts and eutectics under \$0.2 (USD) per kJ latent heat. 
Applied Thermal Engineering

\section{Table Caption List}

Table $1 \quad$ Pure salts obtained from preliminary screening process

Table 2 Thermophysical properties and cost data for the binary eutectic mixtures 
Applied Thermal Engineering

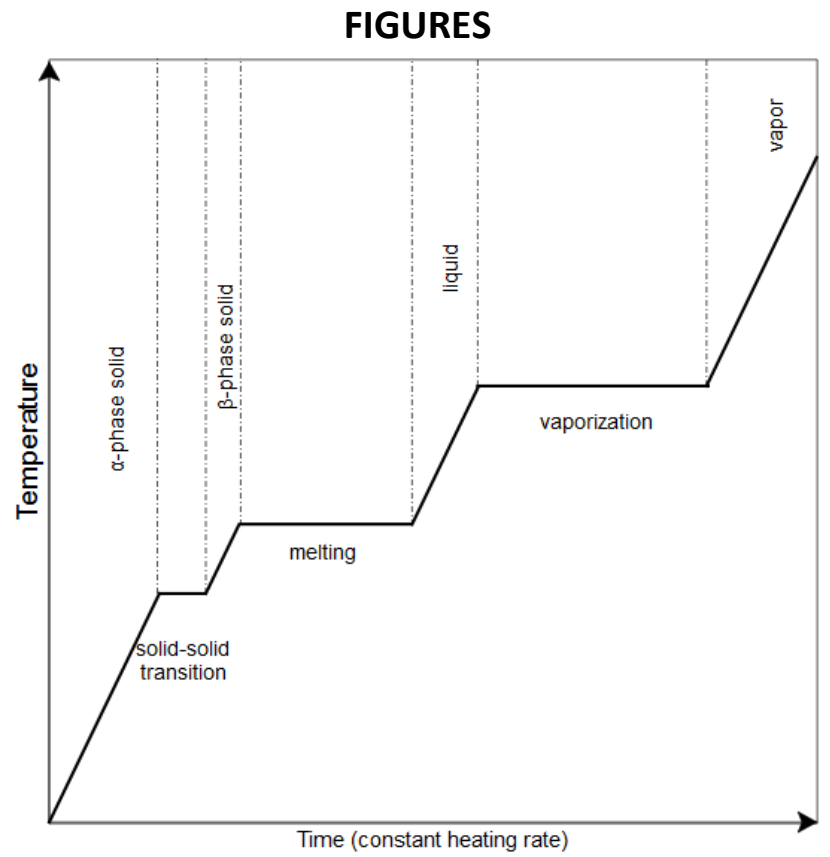

Figure 1 Generalized phase change process [14]. 
Applied Thermal Engineering

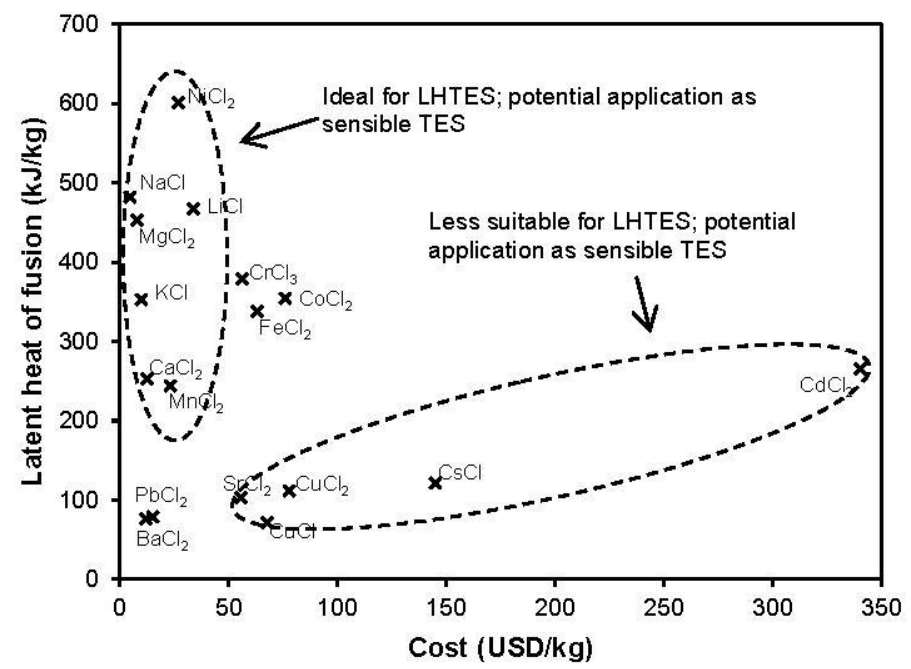

Figure 2 Latent heat plotted against cost for the pure salts considered in this study [15]. 


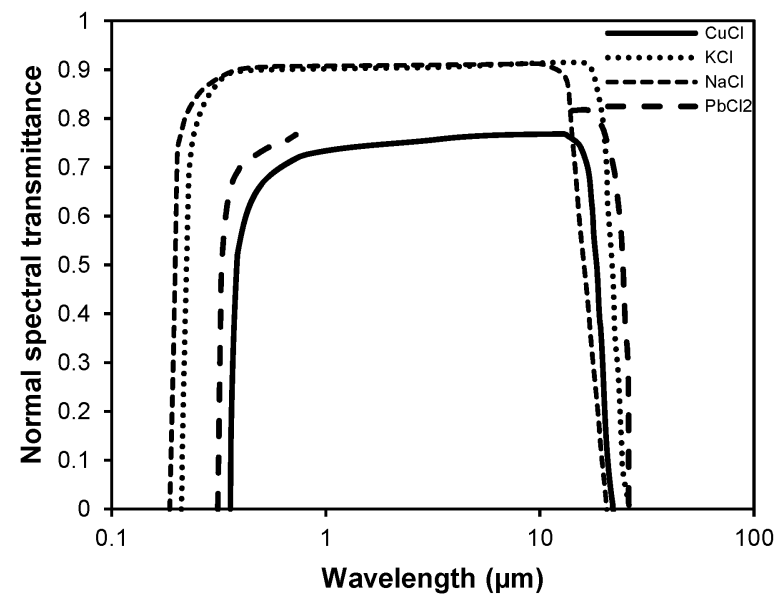

Figure 3 Normal spectral transmittance for select pure chloride salts, taken from Touloukian [54]. 
Applied Thermal Engineering

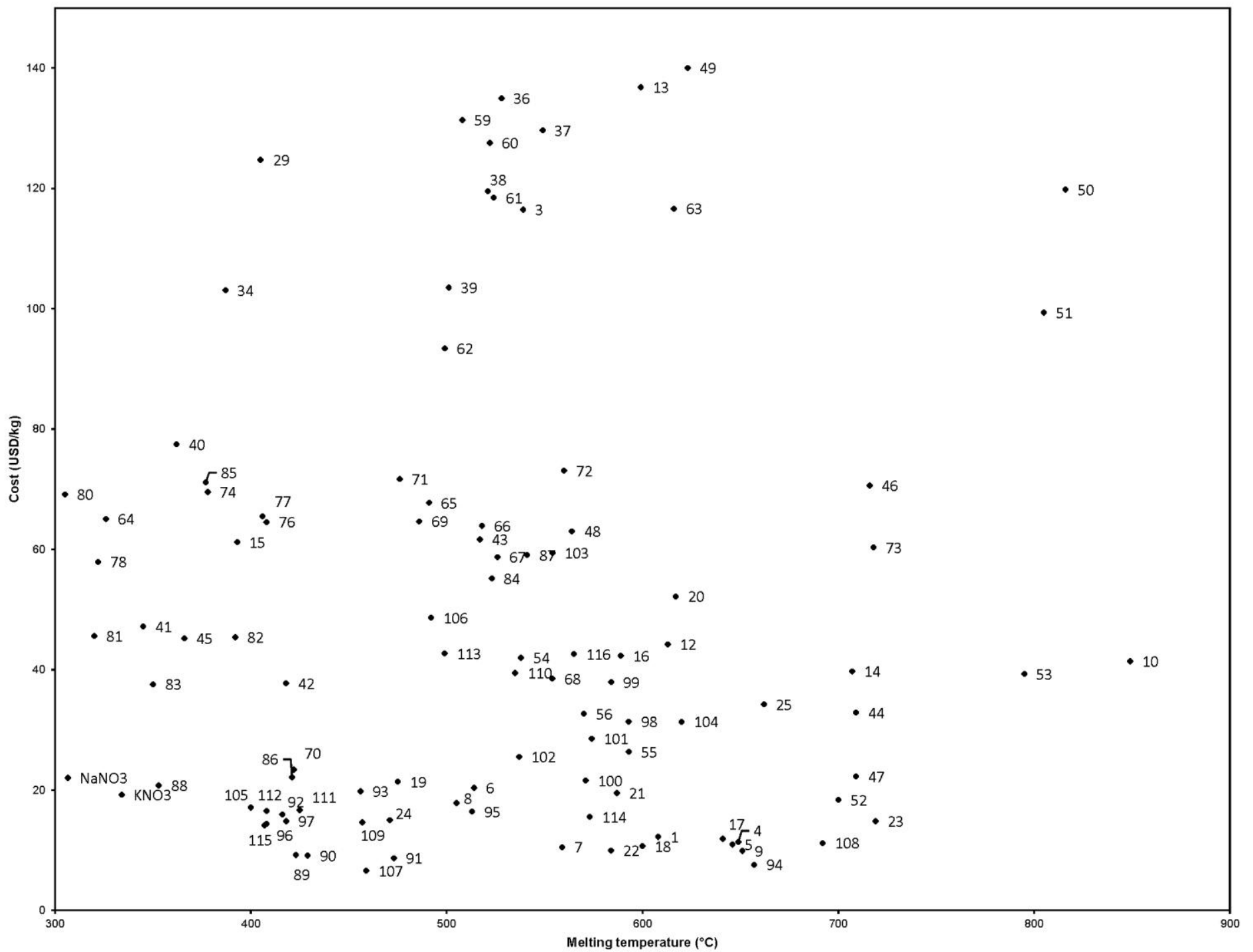

Figure 4 Cost per kg (e.g., sensible storage application) of salt systems at various temperatures (as numbered in Error! Reference source not found.). 
Applied Thermal Engineering

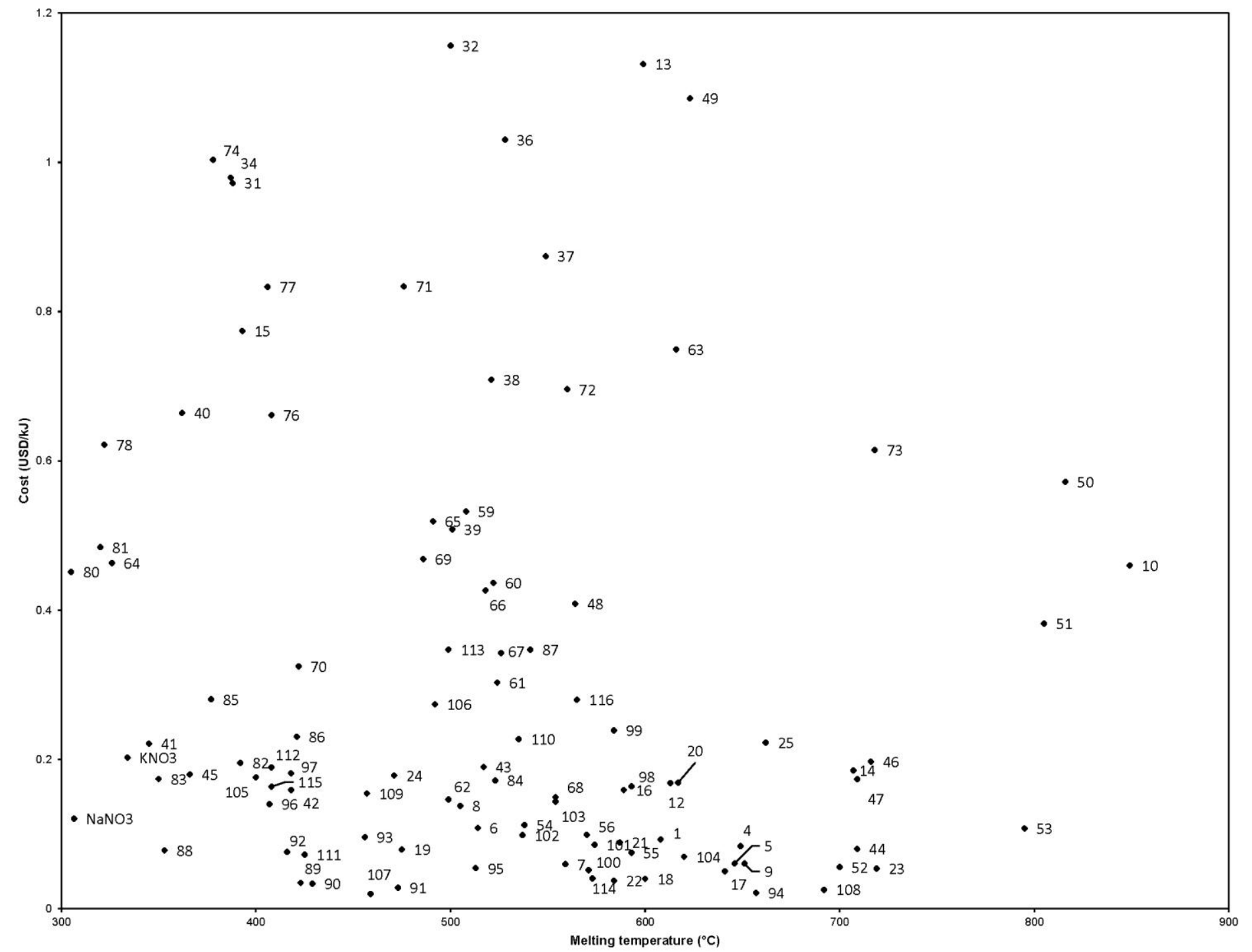

Figure 5 Cost per kJ (e.g., latent storage application) of salt systems at various temperatures (as numbered in Error! Reference source not found.). 
Applied Thermal Engineering

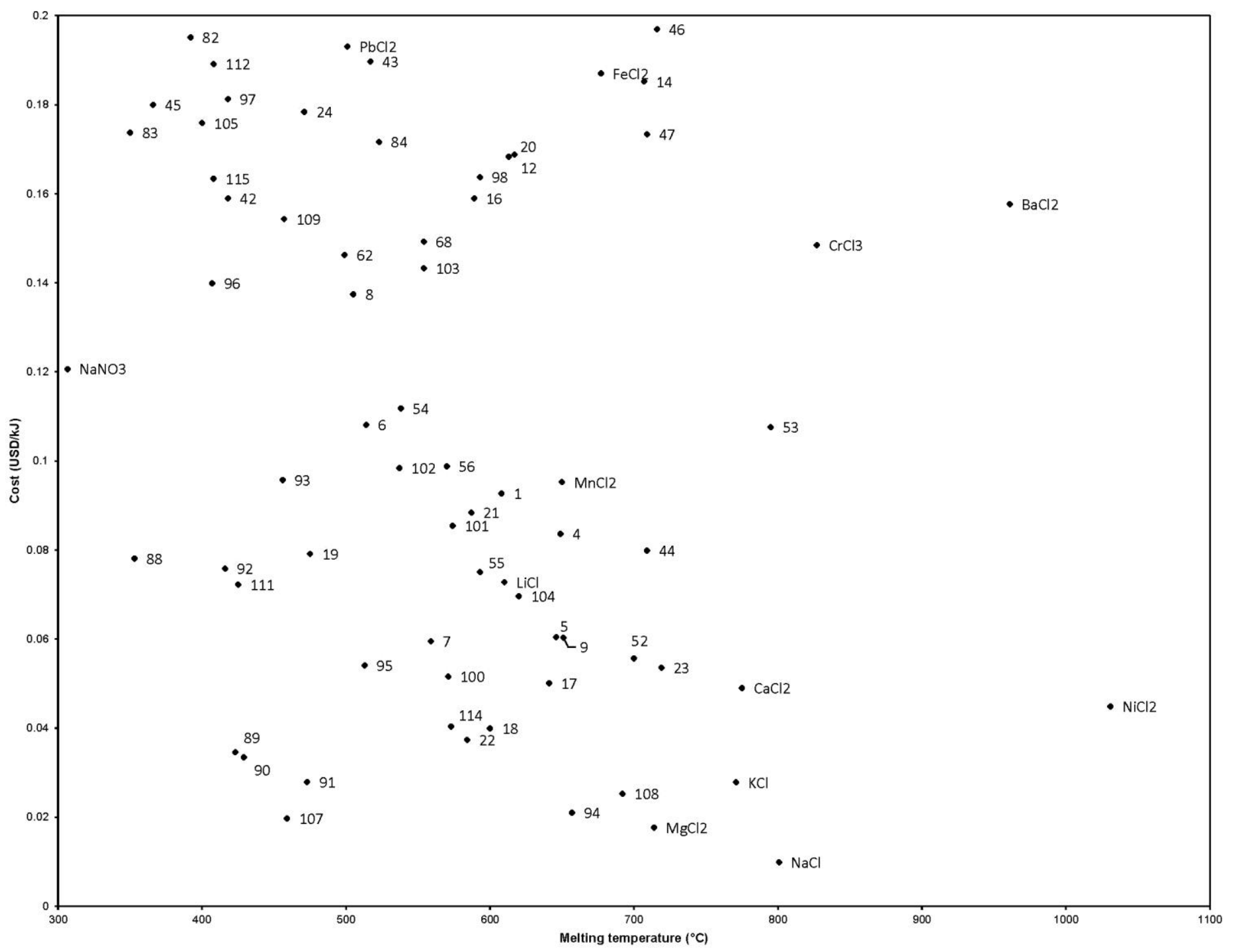

Figure 6 Pure salts and eutectics under \$0.2 (USD) per kJ latent heat. 
TABLES

Table 1: Pure salts obtained from preliminary screening process

\begin{tabular}{|c|c|c|c|c|}
\hline & $\begin{array}{c}\boldsymbol{T}_{m} \\
\left({ }^{\circ} \mathbf{C}\right)\end{array}$ & $\begin{array}{c}\underset{\Delta H_{f u s}}{(\mathrm{~kJ} / \mathrm{kg})} \\
.\end{array}$ & $\begin{array}{c}\text { Cost } \\
\text { (USD/kg) }\end{array}$ & $\begin{array}{c}\text { Cost } \\
(\mathbf{U S D} / \mathbf{k J})\end{array}$ \\
\hline \multicolumn{5}{|c|}{ Alkali metal } \\
\hline \multirow{4}{*}{$\begin{array}{l}\mathrm{LiCl} \\
\mathrm{KCl} \\
\mathrm{NaCl} \\
\mathrm{CsCl}\end{array}$} & 610 & 467 & $\$ 34$ & $\$ 0.07$ \\
\hline & 771 & 353 & $\$ 9.80$ & $\$ 0.03$ \\
\hline & 800.7 & 482 & $\$ 4.76$ & $\$ 0.01$ \\
\hline & 646 & 121 & $\$ 145$ & $\$ 1.20$ \\
\hline \multicolumn{5}{|c|}{ Alkaline earth metal } \\
\hline \multirow{4}{*}{$\begin{array}{l}\mathrm{MgCl}_{2} \\
\mathrm{CaCl}_{2} \\
\mathrm{SrCl}_{2} \\
\mathrm{BaCl}_{2}\end{array}$} & 714 & 453 & $\$ 8.00$ & $\$ 0.02$ \\
\hline & 775 & 253 & $\$ 12.38$ & $\$ 0.05$ \\
\hline & 874 & 102 & $\$ 55.65$ & $\$ 0.54$ \\
\hline & 961 & 76 & $\$ 12.00$ & $\$ 0.16$ \\
\hline \multicolumn{5}{|c|}{ Transition metal } \\
\hline \multirow{4}{*}{$\begin{array}{l}\mathrm{CrCl}_{3} \\
\mathrm{MnCl}_{2} \\
\mathrm{FeCl}_{2} \\
\mathrm{CoCl}_{2}\end{array}$} & 827 & 379 & $\$ 56.25$ & $\$ 0.15$ \\
\hline & 650 & 244 & $\$ 23.23$ & $\$ 0.10$ \\
\hline & 677 & 338 & $\$ 63.20$ & $\$ 0.19$ \\
\hline & 737 & 354 & $\$ 75.80$ & $\$ 0.21$ \\
\hline $\mathrm{NiCl}_{2}$ & 1031 & 595 & $\$ 26.69$ & $\$ 0.04$ \\
\hline \multirow{3}{*}{$\begin{array}{l}\mathrm{CuCl}_{2} \\
\mathrm{CuCl} \\
\mathrm{CdCl}_{2}\end{array}$} & 598 & 112 & $\$ 78$ & $\$ 0.70$ \\
\hline & 423 & 71 & $\$ 67.80$ & $\$ 0.95$ \\
\hline & 589 & 265 & $\$ 340$ & $\$ 1.28$ \\
\hline \multicolumn{5}{|l|}{ Other } \\
\hline $\mathrm{PbCl}_{2}$ & 501 & 79 & $\$ 15.19$ & $\$ 0.19$ \\
\hline
\end{tabular}


Table 2 Thermophysical properties and cost data for the binary eutectic mixtures.

\begin{tabular}{|c|c|c|c|c|c|c|c|c|}
\hline & & $\boldsymbol{x}_{A}$ & $x_{B}$ & & $\begin{array}{c}T_{m} \\
\left({ }^{\circ} \mathbf{C}\right)\end{array}$ & $\begin{array}{c}\Delta H_{f u s, a p p} \\
(\mathbf{k J} / \mathbf{k g})\end{array}$ & $\begin{array}{c}\text { Cost } \\
(\text { USD/kg) }\end{array}$ & $\begin{array}{c}\text { Cost } \\
(\mathrm{USD} / \mathrm{kJ})\end{array}$ \\
\hline No. & Eutectic mixtu & $(A-B)$ & & & & & & \\
\hline 1 & $\mathrm{BaCl}_{2}-\mathrm{CaCl}_{2}$ & 0.359 & 0.641 & & 608 & 131 & $\$ 12.18$ & $\$ 0.09$ \\
\hline 2 & $\mathrm{BaCl}_{2}-\mathrm{CdCl}_{2}$ & 0.43 & 0.57 & [67] & 450 & 140 & $\$ 188.64$ & $\$ 1.34$ \\
\hline 3 & $\mathrm{BaCl}_{2}-\mathrm{CsCl}$ & 0.181 & 0.819 & & 539 & 101 & $\$ 116.45$ & $\$ 1.16$ \\
\hline 4 & $\mathrm{BaCl}_{2}-\mathrm{KCl}$ & 0.445 & 0.555 & & 649 & 135 & $\$ 11.32$ & $\$ 0.08$ \\
\hline 5 & $\mathrm{BaCl}_{2}-\mathrm{KCl}$ & 0.272 & 0.728 & & 656 & 181 & $\$ 10.92$ & $\$ 0.06$ \\
\hline 6 & $\mathrm{BaCl}_{2}-\mathrm{LiCl}$ & 0.249 & 0.751 & & 514 & 188 & $\$ 20.37$ & $\$ 0.11$ \\
\hline 7 & $\mathrm{BaCl}_{2}-\mathrm{MgCl}_{2}$ & 0.429 & 0.571 & & 559 & 176 & $\$ 10.49$ & $\$ 0.06$ \\
\hline 8 & $\mathrm{BaCl}_{2}-\mathrm{MnCl}_{2}$ & 0.36 & 0.64 & {$[67]$} & 505 & 130 & $\$ 17.82$ & $\$ 0.14$ \\
\hline 9 & $\mathrm{BaCl}_{2}-\mathrm{NaCl}$ & 0.399 & 0.601 & & 651 & 163 & $\$ 9.85$ & $\$ 0.06$ \\
\hline 10 & $\mathrm{BaCl}_{2}-\mathrm{SrCl}_{2}$ & 0.27 & 0.73 & {$[51]$} & 849 & 90 & $\$ 41.38$ & $\$ 0.46$ \\
\hline 11 & $\mathrm{CaCl}_{2}-\mathrm{CdCl}_{2}$ & 0.13 & 0.87 & {$[67]$} & 540 & 245 & $\$ 302.89$ & $\$ 1.23$ \\
\hline 12 & $\mathrm{CaCl}_{2}-\mathrm{CoCl}_{2}$ & 0.538 & 0.462 & & 613 & 262 & $\$ 44.16$ & $\$ 0.17$ \\
\hline 13 & $\mathrm{CaCl}_{2}-\mathrm{CsCl}$ & 0.091 & 0.909 & & 599 & 121 & $\$ 136.79$ & $\$ 1.13$ \\
\hline 14 & $\mathrm{CaCl}_{2}-\mathrm{CsCl}$ & 0.854 & 0.146 & & 707 & 214 & $\$ 39.69$ & $\$ 0.19$ \\
\hline 15 & $\mathrm{CaCl}_{2}-\mathrm{CuCl}$ & 0.108 & 0.892 & [71] & 393 & 79 & $\$ 61.18$ & $\$ 0.77$ \\
\hline 16 & $\mathrm{CaCl}_{2}-\mathrm{FeCl}_{2}$ & 0.444 & 0.556 & & 589 & 266 & $\$ 42.29$ & $\$ 0.16$ \\
\hline 17 & $\mathrm{CaCl}_{2}-\mathrm{KCl}$ & 0.74 & 0.26 & & 641 & 237 & $\$ 11.88$ & $\$ 0.05$ \\
\hline 18 & $\mathrm{CaCl}_{2}-\mathrm{KCl}$ & 0.25 & 0.75 & & 600 & 267 & $\$ 10.66$ & $\$ 0.04$ \\
\hline 19 & $\mathrm{CaCl}_{2}-\mathrm{LiCl}$ & 0.35 & 0.65 & & 475 & 270 & $\$ 21.35$ & $\$ 0.08$ \\
\hline 20 & $\mathrm{CaCl}_{2}-\mathrm{MgCl}_{2}$ & 0.474 & 0.526 & & 617 & 309 & $\$ 52.16$ & $\$ 0.17$ \\
\hline 21 & $\mathrm{CaCl}_{2}-\mathrm{MnCl}_{2}$ & 0.374 & 0.626 & & 587 & 220 & $\$ 19.49$ & $\$ 0.09$ \\
\hline 22 & $\mathrm{CaCl}_{2}-\mathrm{NaCl}$ & 0.521 & 0.479 & & 504 & 265 & $\$ 9.89$ & $\$ 0.04$ \\
\hline 23 & $\mathrm{CaCl}_{2}-\mathrm{NiCl}_{2}$ & 0.852 & 0.148 & & 719 & 276 & $\$ 14.79$ & $\$ 0.05$ \\
\hline 24 & $\mathrm{CaCl}_{2}-\mathrm{PbCl}_{2}$ & 0.178 & 0.822 & & 471 & 84 & $\$ 14.97$ & $\$ 0.18$ \\
\hline 25 & $\mathrm{CaCl}_{2}-\mathrm{SrCl}_{2}$ & 0.584 & 0.416 & & 662 & 154 & $\$ 34.20$ & $\$ 0.22$ \\
\hline 26 & $\mathrm{CdCl}_{2}-\mathrm{CsCl}$ & 0.74 & 0.26 & [77] & 440 & 193 & $\$ 292.43$ & $\$ 1.52$ \\
\hline 27 & $\mathrm{CdCl}_{2}-\mathrm{CsCl}$ & 0.35 & 0.65 & [77] & 454 & 145 & $\$ 217.07$ & $\$ 1.50$ \\
\hline 28 & $\mathrm{CdCl}_{2}-\mathrm{CsCl}$ & 0.24 & 0.76 & [77] & 445 & 128 & $\$ 194.89$ & $\$ 1.52$ \\
\hline 29 & $\mathrm{CdCl}_{2}-\mathrm{CuCl}$ & 0.125 & 0.875 & [70] & 405 & 99 & $\$ 124.74$ & $\$ 1.25$ \\
\hline 30 & $\mathrm{CdCl}_{2}-\mathrm{KCl}$ & 0.67 & 0.33 & [59] & 383 & 209 & $\$ 284.90$ & $\$ 1.36$ \\
\hline 31 & $\mathrm{CdCl}_{2}-\mathrm{KCl}$ & 0.38 & 0.62 & [59] & 388 & 214 & $\$ 208.30$ & $\$ 0.97$ \\
\hline 32 & $\mathrm{CdCl}_{2}-\mathrm{LiCl}$ & 0.635 & 0.365 & [59] & 500 & 263 & $\$ 304.10$ & $\$ 1.16$ \\
\hline 33 & $\mathrm{CdCl}_{2}-\mathrm{NaCl}$ & 0.587 & 0.413 & [79] & 396 & 227 & $\$ 278.58$ & $\$ 1.23$ \\
\hline 34 & $\mathrm{CdCl}_{2}-\mathrm{PbCl}_{2}$ & 0.36 & 0.64 & [78] & 387 & 105 & $\$ 103.05$ & $\$ 0.98$ \\
\hline
\end{tabular}




\begin{tabular}{|c|c|c|c|c|c|c|c|c|}
\hline & & $\boldsymbol{x}_{\boldsymbol{A}}$ & $x_{B}$ & & $\begin{array}{c}\boldsymbol{T}_{\boldsymbol{m}} \\
\left({ }^{\circ} \mathbf{C}\right)\end{array}$ & $\begin{array}{c}\Delta H_{\text {fus,app }} \\
(\mathbf{k J} / \mathbf{k g})\end{array}$ & $\begin{array}{c}\text { Cost } \\
(\mathrm{USD} / \mathrm{kg})\end{array}$ & $\begin{array}{c}\text { Cost } \\
(\mathrm{USD} / \mathrm{kJ})\end{array}$ \\
\hline No. & Eutectic mixtu & $(A-B)$ & & & & & & \\
\hline 35 & $\mathrm{CdCl}_{2}-\mathrm{SrCl}_{2}$ & 0.42 & 0.58 & [67] & 502 & 149 & $\$ 185.24$ & $\$ 1.24$ \\
\hline 36 & $\mathrm{CoCl}_{2}-\mathrm{CsCl}$ & 0.18 & 0.82 & [74] & 528 & 131 & $\$ 134.98$ & $\$ 1.03$ \\
\hline 37 & $\mathrm{CoCl}_{2}-\mathrm{CsCl}$ & 0.27 & 0.73 & [74] & 549 & 148 & $\$ 129.64$ & $\$ 0.87$ \\
\hline 38 & $\mathrm{CoCl}_{2}-\mathrm{CsCl}$ & 0.43 & 0.57 & [74] & 521 & 169 & $\$ 119.55$ & $\$ 0.71$ \\
\hline 39 & $\mathrm{CoCl}_{2}-\mathrm{CsCl}$ & 0.66 & 0.34 & [74] & 501 & 204 & $\$ 103.51$ & $\$ 0.51$ \\
\hline 40 & $\mathrm{CoCl}_{2}-\mathrm{CuCl}_{2}$ & 0.256 & 0.744 & [73] & 362 & 117 & $\$ 77.45$ & $\$ 0.66$ \\
\hline 41 & $\mathrm{CoCl}_{2}-\mathrm{KCl}$ & 0.428 & 0.572 & & 345 & 213 & $\$ 47.14$ & $\$ 0.22$ \\
\hline 42 & $\mathrm{CoCl}_{2}-\mathrm{KCl}$ & 0.296 & 0.704 & & 418 & 237 & $\$ 37.70$ & $\$ 0.16$ \\
\hline 43 & $\mathrm{CoCl}_{2}-\mathrm{LiCl}$ & 0.389 & 0.611 & & 517 & 325 & $\$ 61.63$ & $\$ 0.19$ \\
\hline 44 & $\mathrm{CoCl}_{2}-\mathrm{MgCl}_{2}$ & 0.298 & 0.702 & & 709 & 412 & $\$ 32.86$ & $\$ 0.08$ \\
\hline 45 & $\mathrm{CoCl}_{2}-\mathrm{NaCl}$ & 0.373 & 0.627 & & 366 & 251 & $\$ 45.20$ & $\$ 0.18$ \\
\hline 46 & $\mathrm{CoCl}_{2}-\mathrm{NiCl}_{2}$ & 0.894 & 0.106 & & 716 & 358 & $\$ 70.60$ & $\$ 0.20$ \\
\hline 47 & $\mathrm{CoCl}_{2}-\mathrm{PbCl}_{2}$ & 0.22 & 0.78 & [76] & 709 & 128 & $\$ 22.24$ & $\$ 0.17$ \\
\hline 48 & $\mathrm{CoCl}_{2}-\mathrm{SrCl}_{2}$ & 0.41 & 0.59 & {$[75]$} & 564 & 154 & $\$ 62.96$ & $\$ 0.41$ \\
\hline 49 & $\mathrm{CrCl}_{3}-\mathrm{CsCl}$ & 0.06 & 0.94 & [81] & 623 & 129 & $\$ 139.97$ & $\$ 1.09$ \\
\hline 50 & $\mathrm{CrCl}_{3}-\mathrm{CsCl}$ & 0.297 & 0.703 & [81] & 816 & 209 & $\$ 119.76$ & $\$ 0.57$ \\
\hline 51 & $\mathrm{CrCl}_{3}-\mathrm{CsCl}$ & 0.53 & 0.47 & [81] & 805 & 260 & $\$ 99.32$ & $\$ 0.38$ \\
\hline 52 & $\mathrm{CrCl}_{3}-\mathrm{KCl}$ & 0.096 & 0.904 & {$[80]$} & 700 & 330 & $\$ 18.35$ & $\$ 0.06$ \\
\hline 53 & $\mathrm{CrCl}_{3}-\mathrm{KCl}$ & 0.45 & 0.55 & [80] & 795 & 365 & $\$ 39.29$ & $\$ 0.11$ \\
\hline 54 & $\mathrm{CrCl}_{3}-\mathrm{LiCl}$ & 0.13 & 0.87 & [82] & 538 & 375 & $\$ 41.97$ & $\$ 0.11$ \\
\hline 55 & $\mathrm{CrCl}_{3}-\mathrm{NaCl}$ & 0.21 & 0.79 & {$[80]$} & 593 & 351 & $\$ 26.32$ & $\$ 0.08$ \\
\hline 56 & $\mathrm{CrCl}_{3}-\mathrm{NaCl}$ & 0.304 & 0.696 & [80] & 570 & 331 & $\$ 32.67$ & $\$ 0.10$ \\
\hline 57 & $\mathrm{CsCl}-\mathrm{CuCl}$ & 0.215 & 0.785 & {$[68]$} & 233 & 111 & $\$ 88.20$ & $\$ 0.80$ \\
\hline 58 & $\mathrm{CsCl}-\mathrm{CuCl}$ & 0.45 & 0.55 & [68] & 242 & 95 & $\$ 107.76$ & $\$ 1.13$ \\
\hline 59 & CsCl-FeCl ${ }_{2}$ & 0.79 & 0.21 & [83] & 508 & 247 & $\$ 131.36$ & $\$ 0.53$ \\
\hline 60 & $\mathrm{CsCl}-\mathrm{FeCl}_{2}$ & 0.735 & 0.265 & [83] & 522 & 292 & $\$ 127.54$ & $\$ 0.44$ \\
\hline 61 & $\mathrm{CsCl}-\mathrm{FeCl}_{2}$ & 0.61 & 0.39 & [83] & 524 & 391 & $\$ 118.42$ & $\$ 0.30$ \\
\hline 62 & $\mathrm{CsCl}-\mathrm{FeCl}_{2}$ & 0.306 & 0.694 & [83] & 499 & 638 & $\$ 93.41$ & $\$ 0.15$ \\
\hline 63 & $\mathrm{CsCl}-\mathrm{KCl}$ & 0.625 & 0.375 & & 616 & 156 & $\$ 116.62$ & $\$ 0.75$ \\
\hline 64 & $\mathrm{CsCl}-\mathrm{LiCl}$ & 0.42 & 0.58 & & 326 & 140 & $\$ 65.02$ & $\$ 0.46$ \\
\hline 65 & $\mathrm{CsCl}-\mathrm{MgCl}_{2}$ & 0.807 & 0.193 & & 491 & 130 & $\$ 67.72$ & $\$ 0.52$ \\
\hline 66 & $\mathrm{CsCl}-\mathrm{MgCl}_{2}$ & 0.726 & 0.274 & & 518 & 150 & $\$ 63.87$ & $\$ 0.43$ \\
\hline 67 & $\mathrm{CsCl}-\mathrm{MgCl}_{2}$ & 0.626 & 0.374 & & 526 & 171 & $\$ 58.68$ & $\$ 0.34$ \\
\hline 68 & $\mathrm{CsCl}-\mathrm{MgCl}_{2}$ & 0.316 & 0.684 & & 554 & 258 & $\$ 38.48$ & $\$ 0.15$ \\
\hline 69 & $\mathrm{CsCl}-\mathrm{NaCl}$ & 0.65 & 0.35 & & 486 & 138 & $\$ 64.61$ & $\$ 0.47$ \\
\hline
\end{tabular}




\begin{tabular}{|c|c|c|c|c|c|c|c|c|}
\hline & & $\boldsymbol{x}_{A}$ & $x_{B}$ & & $\begin{array}{c}\boldsymbol{T}_{\boldsymbol{m}} \\
\left({ }^{\circ} \mathbf{C}\right)\end{array}$ & $\begin{array}{c}\Delta H_{\text {fus,app }} \\
(\mathbf{k J} / \mathbf{k g})\end{array}$ & $\begin{array}{c}\text { Cost } \\
(\mathrm{USD} / \mathrm{kg})\end{array}$ & $\begin{array}{c}\text { Cost } \\
(\mathrm{USD} / \mathrm{kJ})\end{array}$ \\
\hline No. & Eutectic mixtu & $e(A-B)$ & & & & & & \\
\hline 70 & CsCl-PbCl ${ }_{2}$ & 0.1 & 0.9 & [84] & 422 & 72 & $\$ 23.37$ & $\$ 0.32$ \\
\hline 71 & $\mathrm{CsCl}-\mathrm{PbCl}_{2}$ & 0.56 & 0.44 & {$[84]$} & 476 & 86 & $\$ 71.68$ & $\$ 0.83$ \\
\hline 72 & $\mathrm{CsCl}-\mathrm{SrCl}_{2}$ & 0.856 & 0.144 & & 560 & 105 & $\$ 73.04$ & $\$ 0.70$ \\
\hline 73 & $\mathrm{CsCl}-\mathrm{SrCl}_{2}$ & 0.22 & 0.78 & & 718 & 98 & $\$ 60.29$ & $\$ 0.61$ \\
\hline 74 & $\mathrm{CuCl}-\mathrm{CuCl}_{2}$ & 0.87 & 0.13 & [72] & 378 & 69 & $\$ 69.52$ & $\$ 1.00$ \\
\hline 75 & $\mathrm{CuCl}-\mathrm{KCl}$ & 0.66 & 0.34 & [69] & 149 & 71 & $\$ 51.59$ & $\$ 0.73$ \\
\hline 76 & $\mathrm{CuCl}-\mathrm{LiCl}$ & 0.8 & 0.2 & {$[67]$} & 408 & 98 & $\$ 64.53$ & $\$ 0.66$ \\
\hline 77 & $\mathrm{CuCl}-\mathrm{MgCl}_{2}$ & 0.96 & 0.04 & [71] & 406 & 79 & $\$ 65.50$ & $\$ 0.83$ \\
\hline 78 & $\mathrm{CuCl}-\mathrm{NaCl}$ & 0.76 & 0.24 & [67] & 322 & 93 & $\$ 57.90$ & $\$ 0.62$ \\
\hline 79 & $\mathrm{CuCl}-\mathrm{PbCl}_{2}$ & 0.589 & 0.411 & [70] & 284 & 57 & $\$ 32.96$ & $\$ 0.58$ \\
\hline 80 & $\mathrm{CuCl}_{2}-\mathrm{FeCl}_{2}$ & 0.385 & 0.615 & {$[73]$} & 305 & 153 & $\$ 69.11$ & $\$ 0.45$ \\
\hline 81 & $\mathrm{CuCl}_{2}-\mathrm{KCl}$ & 0.38 & 0.62 & [72] & 320 & 94 & $\$ 45.61$ & $\$ 0.48$ \\
\hline 82 & $\mathrm{FeCl}_{2}-\mathrm{KCl}$ & 0.54 & 0.46 & & 392 & 233 & $\$ 45.38$ & $\$ 0.20$ \\
\hline 83 & $\mathrm{FeCl}_{2}-\mathrm{KCl}$ & 0.389 & 0.611 & & 350 & 216 & $\$ 37.56$ & $\$ 0.17$ \\
\hline 84 & $\mathrm{FeCl}_{2}-\mathrm{LiCl}$ & 0.467 & 0.533 & & 523 & 321 & $\$ 55.13$ & $\$ 0.17$ \\
\hline 85 & $\mathrm{FeCl}_{2}-\mathrm{NaCl}$ & 0.44 & 0.56 & & 377 & 254 & $\$ 71.12$ & $\$ 0.28$ \\
\hline 86 & $\mathrm{FeCl}_{2}-\mathrm{PbCl}_{2}$ & 0.27 & 0.73 & [76] & 421 & 96 & $\$ 22.12$ & $\$ 0.23$ \\
\hline 87 & $\mathrm{FeCl}_{2}-\mathrm{SrCl}_{2}$ & 0.506 & 0.494 & [75] & 541 & 170 & $\$ 59.05$ & $\$ 0.35$ \\
\hline 88 & $\mathrm{KCl}-\mathrm{LiCl}$ & 0.408 & 0.592 & & 353 & 266 & $\$ 20.74$ & $\$ 0.08$ \\
\hline 89 & $\mathrm{KCl}-\mathrm{MgCl}_{2}$ & 0.698 & 0.302 & & 423 & 265 & $\$ 9.16$ & $\$ 0.03$ \\
\hline 90 & $\mathrm{KCl}-\mathrm{MgCl}_{2}$ & 0.653 & 0.347 & & 429 & 271 & $\$ 9.07$ & $\$ 0.03$ \\
\hline 91 & $\mathrm{KCl}-\mathrm{MgCl}_{2}$ & 0.416 & 0.584 & & 473 & 310 & $\$ 8.65$ & $\$ 0.03$ \\
\hline 92 & $\mathrm{KCl}-\mathrm{MnCl}_{2}$ & 0.67 & 0.33 & & 416 & 210 & $\$ 15.90$ & $\$ 0.08$ \\
\hline 93 & $\mathrm{KCl}-\mathrm{MnCl}_{2}$ & 0.37 & 0.63 & & 456 & 206 & $\$ 19.77$ & $\$ 0.10$ \\
\hline 94 & $\mathrm{KCl}-\mathrm{NaCl}$ & 0.494 & 0.506 & & 657 & 360 & $\$ 7.56$ & $\$ 0.02$ \\
\hline 95 & $\mathrm{KCl}-\mathrm{NiCl}_{2}$ & 0.73 & 0.27 & & 513 & 303 & $\$ 16.41$ & $\$ 0.05$ \\
\hline 96 & $\mathrm{KCl}-\mathrm{PbCl}_{2}$ & 0.48 & 0.52 & & 407 & 101 & $\$ 14.12$ & $\$ 0.14$ \\
\hline 97 & $\mathrm{KCl}-\mathrm{PbCl}_{2}$ & 0.22 & 0.78 & & 418 & 82 & $\$ 14.81$ & $\$ 0.18$ \\
\hline 98 & $\mathrm{KCl}-\mathrm{SrCl}_{2}$ & 0.706 & 0.294 & & 593 & 191 & $\$ 31.33$ & $\$ 0.16$ \\
\hline 99 & $\mathrm{KCl}-\mathrm{SrCl}_{2}$ & 0.573 & 0.427 & & 584 & 159 & $\$ 37.91$ & $\$ 0.24$ \\
\hline 100 & LiCl-MgCl${ }_{2}$ & 0.71 & 0.29 & & 571 & 418 & $\$ 21.56$ & $\$ 0.05$ \\
\hline 101 & LiCl- $\mathrm{MnCl}_{2}$ & 0.74 & 0.26 & & 574 & 334 & $\$ 28.50$ & $\$ 0.09$ \\
\hline 102 & LiCl- $\mathrm{MnCl}_{2}$ & 0.44 & 0.56 & & 537 & 259 & $\$ 25.49$ & $\$ 0.10$ \\
\hline 103 & $\mathrm{LiCl}-\mathrm{NaCl}$ & 0.72 & 0.28 & & 554 & 414 & $\$ 59.37$ & $\$ 0.14$ \\
\hline 104 & LiCl-NiCl ${ }_{2}$ & 0.841 & 0.159 & [85] & 620 & 450 & $\$ 31.32$ & $\$ 0.07$ \\
\hline
\end{tabular}


Applied Thermal Engineering

\begin{tabular}{|c|c|c|c|c|c|c|c|c|}
\hline & & $\boldsymbol{x}_{\boldsymbol{A}}$ & $x_{B}$ & & $\begin{array}{c}T_{m} \\
\left({ }^{\circ} \mathbf{C}\right)\end{array}$ & $\begin{array}{c}\Delta H_{\text {fus,app }} \\
(\mathbf{k J} / \mathbf{k g})\end{array}$ & $\begin{array}{c}\Delta H_{f u s} \\
(\mathbf{k J} / \mathbf{k g})\end{array}$ & $\rho_{\mathrm{s}}$ \\
\hline \multicolumn{9}{|c|}{ No. $\quad$ Eutectic mixture $(A-B)$} \\
\hline 105 & LiCl-PbCl ${ }_{2}$ & 0.42 & 0.58 & [86] & 400 & 97 & $\$ 17.06$ & $\$ 0.18$ \\
\hline 106 & $\mathrm{LiCl}-\mathrm{SrCl}_{2}$ & 0.643 & 0.357 & & 492 & 178 & $\$ 48.61$ & $\$ 0.27$ \\
\hline 107 & $\mathrm{MgCl}_{2}-\mathrm{NaCl}$ & 0.431 & 0.569 & & 459 & 333 & $\$ 6.55$ & $\$ 0.02$ \\
\hline 108 & $\mathrm{MgCl}_{2}-\mathrm{NiCl}_{2}$ & 0.869 & 0.131 & & 692 & 443 & $\$ 11.18$ & $\$ 0.03$ \\
\hline 109 & $\mathrm{MgCl}_{2}-\mathrm{PbCl}_{2}$ & 0.2 & 0.8 & [71] & 457 & 95 & $\$ 14.62$ & $\$ 0.15$ \\
\hline 110 & $\mathrm{MgCl}_{2}-\mathrm{SrCl}_{2}$ & 0.462 & 0.538 & & 535 & 174 & $\$ 39.44$ & $\$ 0.23$ \\
\hline 111 & $\mathrm{MnCl}_{2}-\mathrm{NaCl}$ & 0.456 & 0.544 & & 425 & 230 & $\$ 16.65$ & $\$ 0.07$ \\
\hline 112 & $\mathrm{MnCl}_{2}-\mathrm{PbCl}_{2}$ & 0.3 & 0.7 & [67] & 408 & 87 & $\$ 16.50$ & $\$ 0.19$ \\
\hline 113 & $\mathrm{MnCl}_{2}-\mathrm{SrCl}_{2}$ & 0.462 & 0.55 & [67] & 499 & 123 & $\$ 42.68$ & $\$ 0.35$ \\
\hline 114 & $\mathrm{NaCl}-\mathrm{NiCl}_{2}$ & 0.697 & 0.303 & & 573 & 385 & $\$ 15.52$ & $\$ 0.04$ \\
\hline 115 & $\mathrm{NaCl}-\mathrm{PbCl}_{2}$ & 0.29 & 0.71 & & 408 & 88 & $\$ 14.37$ & $\$ 0.16$ \\
\hline 116 & $\mathrm{NaCl}-\mathrm{SrCl}_{2}$ & 0.484 & 0.516 & & 565 & 152 & $\$ 42.57$ & $\$ 0.28$ \\
\hline
\end{tabular}

